\title{
Sifter-T: Um Framework Escalável para Anotação Filogenômica Probabilística Funcional de Domínios Protéicos
}

\author{
Danillo Cunha de Almeida e Silva
}

DISSERTAÇÃO APRESENTADA AO PROGRAMA DE PÓSGRADUAÇÃO INTERUNIDADES EM BIOINFORMÁTICA DA UNIVERSIDADE DE SÃO PAULO COMO REQUISITO PARA A OBTENÇÃO DO GRAU DE MESTRE EM CIÊNCIAS OBTIDO NO PROGRAMA DE BIOINFORMÁTICA.

Área de Concentração: Bioinformática Orientador: Dr. Ricardo Zorzetto Nicoliello Vêncio 


Dedico essa dissertação a todos que de alguma forma me ajudaram nessa conquista. 
"The beautiful thing about learning is that nobody can take it away from you." B.B. King. Jet, Mar. 23, 1992, Vol. 81, no. 22, p. 14. 


\section{AGRADECIMENTOS}

Aos meus pais, Milton e Ana, por acreditarem no meu sucesso.

Aos meus irmãos, Bruno e Patrícia, pelo exemplo de perseverança.

À Thaïs Lodoli, minha companheira, por todo o amor e compreensão.

Aos amigos da banda "Signs of the Beast": Angelo Bordin, Betinho Zampieri, Breno Abarca, Leandro Rizzi, Matheus Calache, Rafael Moretto e Vinícius Zaneti; pela música, pela descontração, pela parceria e pela amizade.

Ao Prof. Dr. Ricardo Z. N. Vêncio pela oportunidade, incentivo, parceria e por toda a sede de ciência que possuo hoje.

Ao Programa de Pós-Graduação Interunidades em Bioinformática.

À secretária do Programa de Pós-Graduação, Patricia Martorelli, por todo o auxílio prestado.

Aos colegas e ex-colegas do LabPIB e LaBiSisMi pela amizade, a parceria e os anos de convivência.

Ao Prof. Dr. Fabio Cozman, Prof. Dr. João Carlos Setubal e Prof. Dr. Robson de Souza que compuseram a banca do meu exame de qualificação.

À FAPESP e Microsoft-Research pelo apoio financeiro.

Ao Departamento de Computação e Matemática.

Aos senhores membros da banca.

A todos que em algum momento contribuíram de alguma forma para minha formação acadêmica. 


\section{RESUMO}

É conhecido que muitos softwares deixam de ser utilizados por sua complexa usabilidade. Mesmo ferramentas conhecidas por sua qualidade na execução de uma tarefa são abandonadas em favor de ferramentas mais simples de usar, de instalar ou mais rápidas. Na área da anotação funcional a ferramenta Sifter (v2.0) é considerada uma das com melhor qualidade de anotação. Recentemente ela foi considerada uma das melhores ferramentas de anotação funcional segundo o "Critical Asssessment of protein Function Annotation" (CAFA) experiment. Apesar disso, ela ainda não é amplamente utilizada, provavelmente por questões de usabilidade e adequação do framework à larga escala.

O workflow SIFTER original consiste em duas etapas principais: A recuperação das anotações para uma lista de genes e a geração de uma árvore de genes reconciliada para a mesma lista. Em seguida, a partir da árvore de genes o Sifter constrói uma rede bayesiana de mesma estrutura nas quais as folhas representam os genes. As anotações funcionais dos genes conhecidos são associadas a estas folhas e em seguida as anotações são propagadas probabilisticamente ao longo da rede bayesiana até as folhas sem informação a priori. Ao fim do processo é gerada para cada gene de função desconhecida uma lista de funções putativas do tipo Gene Ontology e suas probabilidades de ocorrência.

O principal objetivo deste trabalho é aperfeiçoar o código-fonte original para melhor desempenho, potencialmente permitindo que seja usado em escala genômica. Durante o estudo do workflow de pré-processamento dos dados encontramos oportunidades para aperfeiçoamento e visualizamos estratégias para abordá-las. Dentre as estratégias implementadas temos: 0 uso de threads paralelas; balanceamento de carga de processamento; algoritmos revisados para melhor aproveitamento de disco, memória e tempo de execução; adequação do código fonte ao uso de bancos de dados biológicos em formato utilizado atualmente; aumento da acessibilidade do usuário; expansão dos tipos de entrada aceitos; automatização do processo de reconciliação entre árvores de genes e espécies; processos de filtragem de seqüências para redução da dimensão da análise; e outras implementações menores. 
Com isto conquistamos aumento de performance de até 87 vezes para a recuperação de anotações e $73,3 \%$ para a reconstrução da árvore de genes em máquinas quad-core, e redução significante de consumo de memória na fase de realinhamento.

O resultado desta implementação é apresentado como Sifter-T (Sifter otimizado para Throughput), uma ferramenta open source de melhor usabilidade, velocidade e qualidade de anotação em relação à implementação original do workflow de Sifter. Sifter-T foi escrito de forma modular em linguagem de programação Python; foi elaborado para simplificar a tarefa de anotação de genomas e proteomas completos; e os resultados são apresentados de forma a facilitar o trabalho do pesquisador.

Palavras-Chave: Anotação Funcional, Usabilidade, Sifter, Larga Escala 


\section{ABSTRACT}

It is known that many software are no longer used due to their complex usability. Even tools known for their task execution quality are abandoned in favour of faster tools, simpler to use or install. In the functional annotation field, Sifter (v2.0) is regarded as one of the best when it comes to annotation quality. Recently it has been considered one of the best tools for functional annotation according to the "Critical Assessment of Protein Function Annotation" (CAFA) experiment. Nevertheless, it is still not widely used, probably due to issues with usability and suitability of the framework to a high throughput scale.

The original workflow SIFTER consists of two main steps: The annotation recovery for a list of genes and the reconciled gene tree generation for the same list. Next, based on the gene tree, Sifter builds a Bayesian network structure in which its leaves represent genes. The known functional annotations are associated to the aforementioned leaves, and then the annotations are probabilistically propagated along the Bayesian network to the leaves without a priori information. At the end of the process, a list of Gene Ontology functions and their occurrence probabilities is generated for each unknown function gene.

This work main goal is to optimize the original source code for better performance, potentially allowing it to be used in a genome-wide scale. Studying the pre-processing workflow we found opportunities for improvement and envisioned strategies to address them. Among the implemented strategies we have: The use of parallel threads; CPU load balancing, revised algorithms for best utilization of disk access, memory usage and runtime; source code adaptation to currently used biological databases; improved user accessibility; input types increase; automatic gene and species tree reconciliation process; sequence filtering to reduce analysis dimension, and other minor implementations.

With these implementations we achieved great performance speed-ups. For example, we obtained 87-fold performance increase in the annotation recovering module and $72.3 \%$ speed increase in the gene tree generation module using quad-core machines. Additionally, significant memory usage decrease during the realignment phase was obtained. 
This implementation is presented as Sifter-T (Sifter Throughput-optimized), an open source tool with better usability, performance and annotation quality when compared to the Sifter's original workflow implementation. Sifter-T was written in a modular fashion using Python programming language; it is designed to simplify complete genomes and proteomes annotation tasks and the outputs are presented in order to make the researcher's work easier.

Keywords: Functional annotation, Usability, Sifter, High Throughput 


\section{LISTA DE TABELAS E QUADROS}

\section{Tabelas}

Tabela 1 - Códigos de evidência do Gene Ontology (The Gene Ontology Consortium, 2011), e probabilidades de correção correspondentes no SIFTER.

\section{Quadros}

Quadro I - Número de anotações funcionais para cada tipo de evidência no banco de dados GOA.

Quadro II - Maiores famílias de proteína e consumo de memória para ferramentas MAFFT e MUSCLE.

Quadro III - Redução de consumo de memória por remoção de proteínas não anotadas.

Quadro IV - Redução de consumo de memória por remoção de proteínas anotadas com código IEA. 


\section{LISTA DE FIGURAS}

Figura 1 - Limites da anotação do tipo "Função Molecular", "Processo Biológico" e "Componente Celular" de proteínas em organismos modelo.

Figura 2 - Representação simplificada de um grafo direcionado acíclico.

Figura 3 - Representação simplificada de uma rede bayesiana em grafo direcionado acíclico.

Figura 4 - Representação expandida (urolled) de um grafo direcionado acíclico, comumente utilizada para representar uma rede bayesiana dinâmica.

Figura 5 - Representação simplificada dos principais passos envolvidos na anotação funcional pela metodologia SIFTER.

Figura 6 - Ilustração dos principais elementos utilizados pelo Sifter na propagação das probabilidades de funções através de uma árvore de genes

Figura 8 - Exemplo da estrutura dos arquivos ".pli" gerados ao final do script "pfam2sifter.py".

Figura 9 - Diagrama de classes para o motor de inferência SIFTER.

Figura 10 - Ilustração de como lidamos com politomias em árvores de espécies. $\mathbf{5 5}$

Figura 11 - Workflow SIFTER modificado.

Figura 12 - Linhas de tendência representando os tempos de execução em máquina quad-core para o script "pull_alignments.py" em relação ao número de famílias de proteínas de entrada.

Figura 13 - Linhas de tendência representando os tempos de execução para o script "pfam2sifter.py" original e novas implementações em relação ao número de famílias de proteínas de entrada. 


\section{SUMÁRIO}

Resumo vii

Abstract $\quad$ ix

Lista de Tabelas e Quadros _ xi

Lista de Figuras $\quad$ xii

1. Introdução $\quad 15$

1.1. Motivação 18

1.2. Objetivos 19

1.3. Contribuições desta dissertação 20

1.4. Organização do trabalho 21

2. Definições e Revisão da Literatura 22

2.1. Filogenômica 22

2.2. Redes Bayesianas 24

2.2.1. Cadeias de Markov 26

2.3. Repositórios Públicos em Larga Escala 28

2.3.1. NCBI Taxonomy 28

2.3.2. UNIPROT 28

2.3.3. Gene Ontology 29

2.3.4. Gene Ontology Annotation 29

2.3.5. PFAM 30

2.4. Metodologia SIFTER 30

2.5. Modelo matemático de propagação 34

3. Estudo da Implementação Original e Levantamento de Requisitos 38

3.1. Estudo da implementação da metodologia SIFTER 38

3.1.1. Workflow original 38

3.1.2. Motor de Inferência $\quad 42$

3.2. Levantamento das questões passíveis de tratamento 44

3.2.1. Bancos de dados biológicos 44

3.2.1.1. Formato do arquivo das ontologias funcionais $\quad 44$

3.2.1.2. Tipos de evidência $\quad 45$

3.2.1.3. Reconstrução de Árvores de Genes e Árvores de Espécies 45

3.2.2. Design Centrado no Usuário 46

3.2.2.1. Tipo de dados de entrada 46

3.2.2.2. Estrutura do arquivo de saída 47

3.2.2.3. Dificuldade no uso da ferramenta e documentação 47

3.2.3. Uso em larga escala $\quad 48$ 
4. Metodologia e Resultados - Workflow 49

4.1. Bancos de dados biológicos $\quad 49$

4.1.1. Formato do arquivo das ontologias funcionais 49

4.1.2. Tipos de evidência $\quad 50$

4.1.3. Reconstrução de Árvores de Genes e Árvores de Espécies 52

4.2. Design Centrado no Usuário 56

4.2.1. Tipo de dados de entrada $\quad 56$

4.2.1.1. Aminoácidos $\quad 56$

4.2.1.2. Nucleotídeos $\quad 57$

4.2.1.3. Incorporação das sequências de entrada aos alinhamentos múltiplos 59

4.2.2. Estrutura do arquivo de saída $\quad 59$

4.2.3. Dificuldade no uso da ferramenta e documentação 61

4.3. Visão global da nova implementação 62

5. Metodologia e Resultados - Performance 65

5.1. Perfilagem e otimizações de performance 65

5.2. Gargalos de Memória e Sistemas de filtragem 69

5.2.1. Alinhamento múltiplo $\quad 69$

$\begin{array}{ll}\text { 5.2.2. Filtragem de Sequências } & 70\end{array}$

5.3. Redução de redundância de processamento 73

$\begin{array}{ll}\text { 6. Conclusão e Perspectivas } & 75\end{array}$

$\begin{array}{ll}\text { Referências } & 78\end{array}$ 


\section{CAPÍtulo 1 \\ INTRODUÇÃO}

Nos últimos anos, a geração de dados em larga escala tem alcançado patamares espantosos e resultam no rápido acúmulo de sequências genômicas para diversos grupos de organismos. Já a anotação funcional destas sequências cresce numa taxa bem menor. Mesmo E. coli, um dos organismos modelo mais bem conhecidos e estudados, possuem dezenas de genes associados a proteínas hipotéticas (http://ecocyc.org/ - janeiro de 2012; Figura 1). Mais recentemente ainda, com o lançamento comercial dos sequenciadores de nova geração (Horner et al., 2009), emergiu a necessidade de abordagens de anotação capazes de acompanhar o ritmo de crescimento do volume de dados. Segundo Kodama et al. (2011) o "Sequence Read Archive" (http://www.ncbi.nlm.nih.gov/sra), um repositório público de dados de sequenciamento de nova geração, ultrapassou 100 terabytes de sequências em 2011. Considerando o passo lento da anotação experimental, é possível afirmar que somente a abordagem computacional tem capacidade de lidar com tamanho volume de dados (Rodrigues et al., 2007).

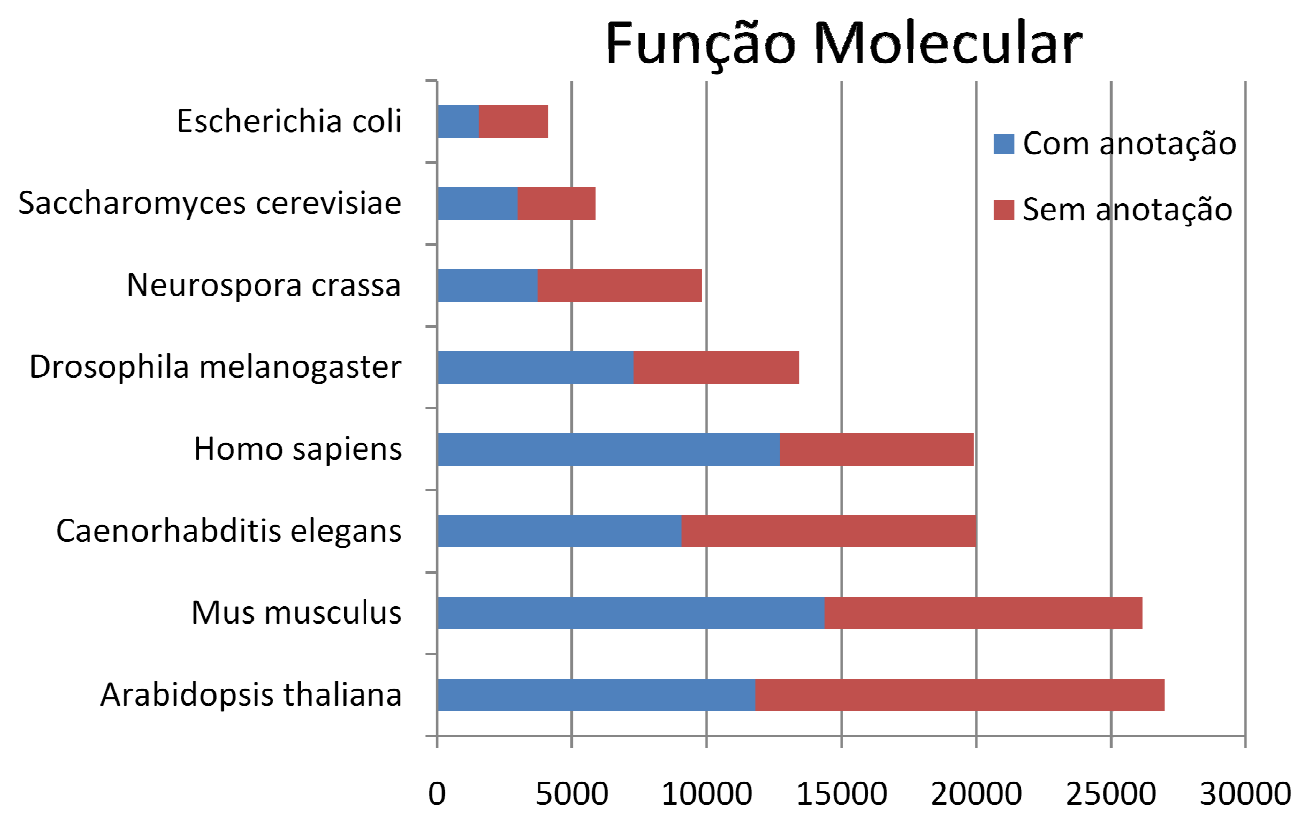



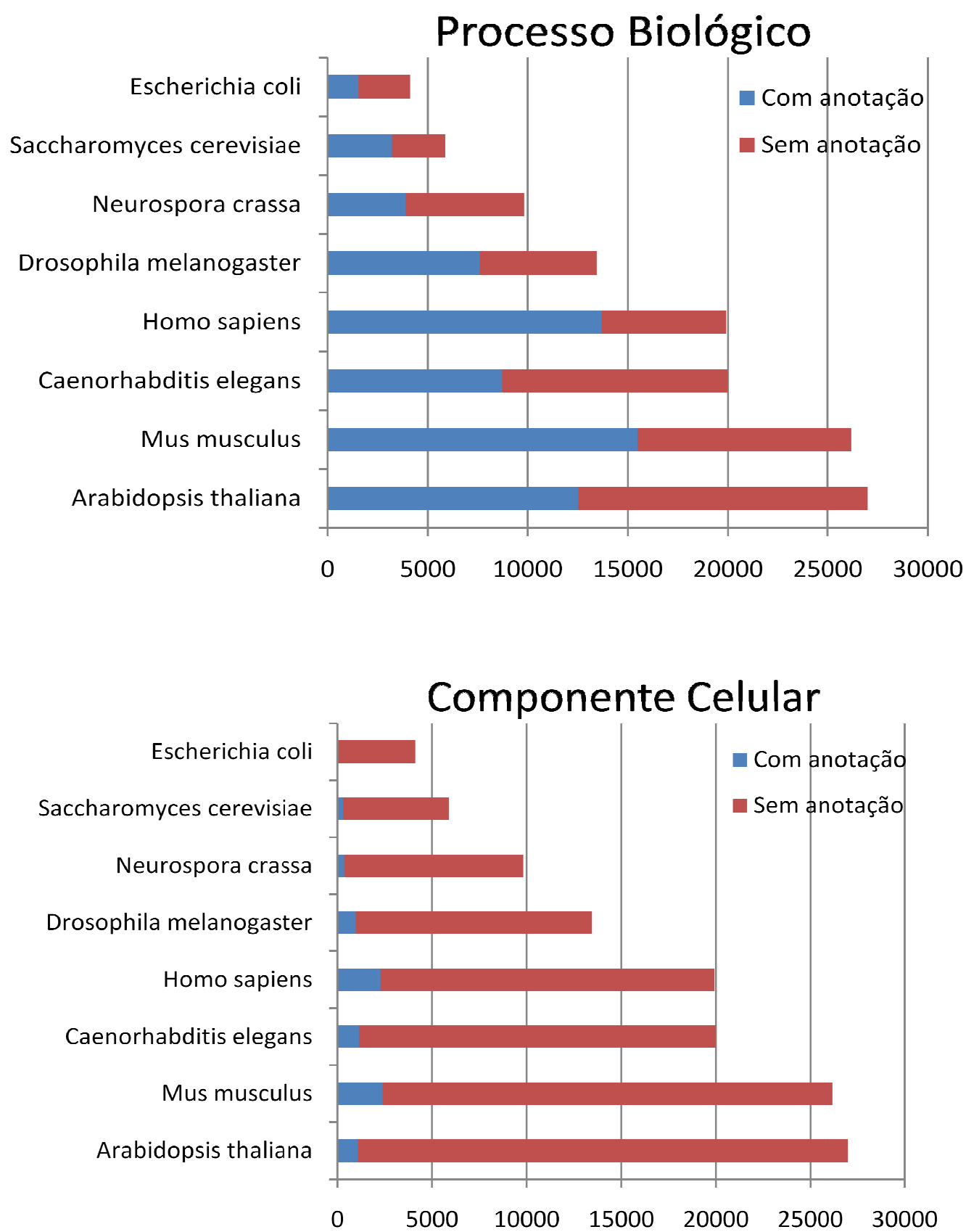

Figura 1 - Limites da anotação do tipo "Função Molecular", "Processo Biológico" e "Componente Celular" de proteínas em organismos modelo. Para cada espécie o gráfico dá a fração de proteínas anotadas ou não, em relação ao número total de sequências codificantes e de acordo com as ontologias do Gene Ontology Annotation (parte do Gene Ontology Consortium). Valores obtidos em http://www.pantherdb.org, baseados em dados de 2009.

Acompanhando a geração de dados foram desenvolvidos vários métodos e ferramentas de bioinformática para a análise de grandes conjuntos de dados, como genomas inteiros (Abhiman \& Sonnhammer, 2005 apud Nahum \& Pereira, 2008; Dehal 
\& Boore, 2006 apud Nahum \& Pereira, 2008; Glanville et al., 2007 apud Nahum \& Pereira, 2008; Korbel et al., 2002 apud Nahum \& Pereira, 2008; Krishnamurthy et al., 2006 apud Nahum \& Pereira, 2008; Nahum et al., 2006 apud Nahum \& Pereira, 2008).

A abordagem computacional, entretanto, possui seus reveses. Muitas das abordagens computacionais se baseiam somente na busca de similaridade entre as sequências ou estruturas, e a transferência de informações da sequência similar para o gene ou proteína de interesse. Esta propagação de informações pode também propagar erros (Nahum \& Pereira, 2008). O aumento de número de sequências nos bancos de dados biológicos pode comprometer a transferência de função baseada em homologia (inferida por similaridade). Isso pode ocorrer, pois a transferência pode ser incorreta mesmo em casos de alta similaridade. Com isso a propagação de anotações errôneas aumenta com o aumento do número de sequências nos bancos de dados, podendo gerar grandes grupos de anotações incorretas baseadas em uma única anotação incorreta propagada por transferência de função baseada em homologia (Friedberg, 2006).

Atualmente existem abordagens que podem melhorar a anotação automática, entre elas o uso de árvores evolutivas para a transferência de informação, metodologia chamada de tree annotation, ou anotação em árvore (Nahum \& Pereira, 2008). Esse tipo de abordagem, na qual funções conhecidas são sobrepostas numa árvore evolucionária com todos os homólogos, é conhecida como metodologia filogenômica (Eisen, 1998). Uma das melhores ferramentas de anotação funcional que se aproveita da metodologia filogenômica é Sifter (Engelhardt et al., 2005). 


\section{1 - Motivação}

$\mathrm{Na}$ área da anotação funcional Sifter (v2.0) é considerado uma das ferramentas com melhor qualidade de anotação. Recentemente ela foi considerada uma das melhores ferramentas de anotação funcional segundo o "Critical Assessment of protein Function Annotation" (CAFA) experiment (Radivojac et al., 2013). Apesar disso, ela ainda não é amplamente utilizada, provavelmente por questões de usabilidade e adequação do framework à larga escala.

Atualmente a ferramenta Sifter, em sua última versão (v2.0; Engelhardt et al., 2011), é uma ferramenta difícil de utilizar por pesquisadores interessados somente na anotação funcional fornecida. Sua documentação é muito pobre; seu software não está preparado para lidar com versões mais atuais dos bancos de dados biológicos; seu workflow está incompleto; em vários passos o pesquisador é obrigado a conhecer a linguagem de programação e alterar parâmetros manualmente; seu tipo de dado de entrada padrão é uma lista de famílias de proteínas (segundo o banco de dados PFam), algo distante do tipo de dado que o pesquisador possui; possui baixa escalabilidade; entre outras questões menores. Outros grupos tentaram explorar a metodologia Sifter para anotação funcional, mas conseguiram se aproveitar de forma muito limitada. A ferramenta Afawe (Joker et al., 2008), por exemplo, é capaz de anotar seqüências pela metodologia Sifter somente se a seqüência já estiver em seu banco de dados.

É conhecido que muitos softwares na área da bioinformática deixam de ser utilizados por sua precária usabilidade (Veretnik et al., 2008). Mesmo ferramentas conhecidas por sua qualidade na execução de uma tarefa são abandonadas em favor de ferramentas mais simples de usar, de instalar ou mais rápidas. Visando solucionar esta questão alguns grupos incentivaram e propuseram estratégias para o desenvolvimento centrado no usuário (Veretnik et al., 2008; Bolchini et al., 2009; Pavelin et al., 2012; de Matos et al., 2013). Baseado nestas estratégias elaboramos uma metodologia para tornar a anotação funcional probabilística de Sifter acessível a pesquisadores com níveis diversos de conhecimento de bioinformática, e a desenvolvedores interessados em aperfeiçoar esta implementação. 


\section{2 - Objetivos}

O principal objetivo deste trabalho é aperfeiçoar o código-fonte original da metodologia Sifter para melhor desempenho, potencialmente permitindo que seja usado em escala genômica; e aperfeiçoar a usabilidade da metodologia, potencialmente permitindo que uma gama maior de pesquisadores tenha acesso às anotações funcionais de qualidade de Sifter. Para isso precisamos primeiramente compreender profundamente a metodologia Sifter de anotação funcional automática, uma vez que se encontra ainda em estágio de protótipo.

Como objetivo secundário esperamos re-anotar organismos de interesse para bioenergia. Visando ampliar a utilidade dos testes de escalabilidade selecionamos um conjunto de dados de teste baseado principalmente em genomas ou proteomas de organismos de interesse para bioenergia. Desta forma estaremos gerando ao final reanotações funcionais de qualidade para organismos que possuem anotações funcionais potencialmente desatualizadas ou ainda inexistentes.

\section{Objetivos primários:}

I. O estudo de Redes Bayesianas, Anotação Probabilística e Metodologia Sifter;

II. Estudo da atual implementação do workflow Sifter e levantamento de questões a serem tratadas;

III. Elaboração de um framework automatizado e de fácil utilização;

IV. Aprimoramento da velocidade e confiabilidade da metodologia Sifter;

\section{Objetivo secundário:}

V. Aplicação da metodologia para a anotação de genomas e proteomas de interesse para Bioenergia. 


\section{3 - Contribuições desta dissertação}

A principal contribuição desta dissertação é o software Sifter-T (Sifter otimizado para Throughput), uma ferramenta open source de melhor usabilidade, velocidade e qualidade de anotação em relação à implementação original do workflow de Sifter. Sifter-T foi escrito de forma modular em linguagem de programação Python; foi elaborado para simplificar a tarefa de anotação de genomas e proteomas completos; e os resultados são apresentados de forma a facilitar o trabalho do pesquisador.

De forma a assegurar a maior disponibilidade e persistência do código fonte (outra deficiência apontada por Veretnik et al., 2008) de Sifter-T, ele será disponibilizado em três vias:

1 - Link em repositório institucional (LabPIB):

http://labpib.fmrp.usp.br/methods/sifter-t/

2 - Material suplementar da publicação principal deste software (em preparação).

3 - Link no repositório Github:

https://github.com/dcasbioinfo/sifter-t.git

Sistemas de versionamento como o Git facilitam a colaboração com outras pessoas; aumentam a reprodutibilidade de testes (você pode facilmente recuperar versões anteriores do código); oferece um sistema de segurança para perda dos dados; com o sistema de ramos (branches) de desenvolvimento é possível testar novas funcionalidades instáveis sem comprometer o funcionamento da versão de produção; aumenta a reusabilidade do código; facilita a interação do usuário com o desenvolvedor; entre outras qualidades (Ram, 2013). O Github é o maior site de hospedagem do tipo Git da atualidade (Ram, 2013), tornando-o a melhor opção para estender a persistência do código. 


\section{4 - Organização do trabalho}

O restante do trabalho está organizado da seguinte forma:

- Capítulo 2 - Apresenta definições e a revisão da literatura de forma a embasar a compreensão da metodologia e ao final apresenta de forma simplificada o funcionamento da metodologia Sifter.

- Capítulo 3 - Descreve o funcionamento da implementação original do workflow Sifter, desde o tipo de arquivo de entrada até o resultado da anotação. Ao final são levantadas questões passíveis de tratamento.

- Capítulo 4 - Apresenta metodologia, resultados e breve discussão acerca da alteração do workflow Sifter voltadas ao usuário final.

- Capítulo 5 - Apresenta metodologia, resultados e breve discussão acerca da otimização de performance (tempo de execução, aproveitamento de memória e acesso a disco) da metodologia Sifter.

- Capítulo 6 - Conclui a dissertação, discute nossa contribuição e aponta caminhos para trabalhos futuros.

As questões abordadas pelos capítulos 4 e 5 foram tratadas concomitantemente, mas optamos por separar os conteúdos para facilitar a exposição. 


\section{CAPÍtulo 2 \\ DEFINIÇÕES E REVISÃO DA LITERATURA}

Este trabalho almeja utilizar a metodologia Sifter de anotação funcional probabilística como base para criar um framework de anotação rápido e simples de usar. Com base nisso, a seção 2.1 e 2.2 apresentam, respectivamente, revisões sobre os conceitos de Filogenômica e Redes Bayesianas, conceitos chave para a compreensão do funcionamento da ferramenta Sifter; em seguida são apresentados os principais bancos de dados biológicos (seção 2.3) dos quais a metodologia Sifter aproveita informações; por fim é apresentado o funcionamento geral da metodologia Sifter (seção 2.4), e o funcionamento um pouco mais aprofundado da estatística envolvida na atualização das probabilidades para cada nó do grafo (seção 2.5).

\subsection{Filogenômica}

Similaridade entre sequências é um passo essencial para a predição de funções baseada em homologia. A similaridade pode ser aferida analisando seqüências de DNA, RNA ou proteínas; em suas estruturas primárias, secundárias ou terciárias; e pode ser analisada em diferentes níveis: motivos (motifs), domínios, genes/proteínas completas ou suas estruturas secundária e terciária (Eisen \& Wu, 2002).

Em muitos casos similaridade não é suficiente para inferir homologia, pois isoladamente não é capaz de detectar significância biológica. Neste contexto surge a filogenômica, descrita por Eisen \& Fraser (2003) como a interseção entre a genômica e a evolução. Incorporando informações evolutivas é possível aumentar a confiabilidade da inferência de homologia, reduzindo as restrições para a transferência de informação entre genes relacionados (Eisen \& Wu, 2002).

A transferência ou extrapolação de informação entre genes evolutivamente relacionados já é usada há algum tempo para melhorar a acurácia da predição de 
proteínas (Sjölander, 2004). A abordagem filogenômica pressupõe que sequências ortólogas (que divergiram por especiação) têm mais chance de manter a função que sequências parálogas (que divergiram por duplicação), por reduzirem a pressão +seletiva sobre a sequência sobressalente (Sjölander, 2004; Zmasek \& Eddy, 2001; Nahum \& Pereira, 2008). A adição de informações taxonômicas, contexto genômico (vizinhança gênica), organização dos genes (introns, exons), arquitetura protéica (domínios estruturais e de sequência) e motivos conservados à estrutura da árvore, enriquecem e melhoram a acurácia da anotação (Nahum \& Pereira, 2008).

Em estudos genômicos comparativos duas abordagens são comumente utilizadas para a inferência de genes ortólogos. O método mais comum é a determinação de relações simétricas de melhor correspondência (mais conhecida como Bidirectional Best Hit - BBH), facilmente determinadas por meio de ferramentas de busca de similaridade de sequências, como a conhecida ferramenta BLAST (Kristensen et al., 2011). Outra forma é a reconciliação, processo baseado no princípio da parcimônia que utiliza a diferença entre a árvore de genes e a árvore de espécies para determinar os pontos de duplicação (Zmasek \& Eddy, 2001).

Entretanto, a anotação automática baseada em ortologias possui certos limites. Innan e Kondrashov (2010) chamam a atenção para diferentes modelos de evolução possíveis após eventos de duplicação gênica, como a neofuncionalização, a subfuncionalização, a especialização, a dosagem positiva, a proteção contra mutações deletérias e a heterozigose permanente. Estes distintos processos ainda não podem ser detectados de forma automática pelas metodologias atuais. Outro desafio importante surge ao analisarmos grupos fora dos eucariotos multicelulares, principalmente os vírus e bactérias. Nestes grupos de organismos a evolução não segue uma estrutura em árvore, sendo a transferência lateral de genes o principal componente de evolução destes organismos (Bapteste et al., 2009; Treange \& Rocha, 2011). Ainda não existem algoritmos eficientes para a determinação de ortólogos nestes grupos de organismos, mas idéias baseadas em Redes Filogenéticas (numa clara intenção de tentar estender as Árvores Filogenéticas) existem (Dagan, 2011). 


\subsection{Redes Bayesianas}

As redes Bayesianas, ou redes causais, são modelos de grafos (graphical models) baseados em probabilidades (Figura 2). Cada nó representa uma variável no grafo e a dependência entre as variáveis é representada pelos arcos. A informação sobre os valores observados para as variáveis pode ser propagada pela rede, atualizando as probabilidades das variáveis não observadas diretamente (Heckerman, 1995; Koski \& Noble, 2009).

Em certas situações, os arcos entre as variáveis numa rede bayesiana podem ser interpretados como representações gráficas de relacionamentos causais. Isso ocorre quando o grafo é usado pra modelar uma situação na qual os predecessores de uma variável podem ser classificados como a causa imediata do valor da variável. Esta relação é probabilística e a relação entre o valor tomado pela variável e suas predecessoras é especificada por uma distribuição probabilística condicional (Koski \& Noble, 2009). Portanto, nessas redes, pode-se calcular a probabilidade de um evento ocorrer, condicionado à ocorrência de outro.

O uso de redes bayesianas para modelar a incerteza sobre um evento aumenta a consistência do sistema ao incorporar evidências, principalmente quando a evidência é esparsa (Heckerman, 1995; Koski \& Noble, 2009; Engelhardt et al., 2005).

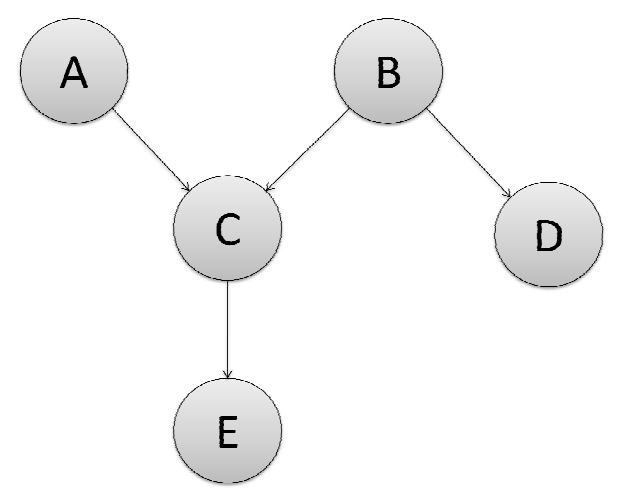

Figura 2 - Representação simplificada de um grafo direcionado acíclico. Em uma rede bayesiana, os círculos representam os nós e as setas representam as relações causais.

Para poder propagar as probabilidades entre os nós (atualizar as probabilidades) fazemos uso do "teorema da probabilidade condicional": 
$p(A \mid B)=\frac{p(A \cap B)}{p(B)}$, que pode ser descrito como a probabilidade de A ocorrer, fornecida a evidência $B(" p(A \mid B)$ "), sendo igual à probabilidade da intersecção de $A$ e $B$ (“ $p(A \cap B)$ "), dividido pela probabilidade de B (“ $\mathrm{p}(\mathrm{B})$ ”).

Articulando esta equação, temos:

$$
p(A \cap B)=p(A \mid B) p(B)
$$

Como $p(A \cap B)=p(B \cap A)$, temos:

$$
p(A \mid B) p(B)=p(B \mid A) p(A)
$$

Articulando novamente, temos:

$$
p(A \mid B)=\frac{p(B \mid A) p(A)}{p(B)}
$$

Sendo uma sequência de eventos mutuamente exclusivos $\left\{A_{1}, A_{2}, A_{3}, \ldots, A_{n}\right\}$, podemos definir o "teorema da probabilidade total" como a soma de todas as probabilidades condicionais de um dado evento:

$$
p(B)=p\left(A_{1}\right) p\left(B \mid A_{1}\right)+p\left(A_{2}\right) p\left(B \mid A_{2}\right)+\ldots+p\left(A_{n}\right) p\left(B \mid A_{n}\right)
$$

Se aplicarmos (2) em (1), temos a regra de Bayes (Koski \& Noble, 2009):

$$
p\left(A_{i} \mid B\right)=\frac{p\left(B \mid A_{i}\right) p\left(A_{i}\right)}{p\left(A_{1}\right) p\left(B \mid A_{1}\right)+p\left(A_{2}\right) p\left(B \mid A_{2}\right)+\ldots+p\left(A_{n}\right) p\left(B \mid A_{n}\right)}
$$

No caso de hipóteses $\mathrm{H}_{\mathrm{i}}$ e um conjunto finito de hipóteses mutuamente exclusivas $\left\{\mathrm{H}_{\mathrm{i}}\right\}_{\mathrm{i}=1}^{\mathrm{m}}$,

$$
p(E)=\sum_{i=1}^{m} p\left(E \mid H_{i}\right) p\left(H_{i}\right)
$$

O intuito deste trabalho não é discorrer sobre toda a teoria envolvida em redes bayesianas, entretanto é necessário para o entendimento da metodologia SIFTER 
(Engelhardt et al., 2005; Engelhardt et al., 2006) pelo menos introduzir a notação básica de redes bayesianas (Koski \& Noble, 2009):

- O conjunto universo é representado por $\Omega$. Ele representa o contexto do experimento. O conjunto universo consiste em todos os possíveis valores para as variáveis desconhecidas.

- O espaço amostral será representado por $\chi$, conjunto de todas as possíveis saídas do experimento.

- $\quad \Theta$ será usado para o espaço de parâmetros. $\Omega=\chi \times \mathrm{x} \Theta$

- O espaço de eventos $\mathcal{F}$ é uma coleção de subconjuntos de $\Omega$

Como a rede bayesiana é modelada em probabilidades:

- $p(\varnothing)=0$

$-p(\Omega)=1$

Qualquer subconjunto de $\Omega$ terá uma probabilidade entre 0 e 1 de ocorrer.

\subsubsection{Cadeias de Markov}

A atualização do cálculo das probabilidades de todos os nós de uma rede bayesiana ao longo do tempo é uma tarefa muito intensiva computacionalmente. Entretanto no caso de redes bayesianas dinâmicas é possível remodelar como uma cadeia de Markov, muito menos intensiva computacionalmente.

As cadeias de Markov, nomeadas em homenagem ao matemático Andrei Markov, são um processo aleatório que sofre transições entre estados discretos finitos. Elas possuem a propriedade de Markov, que consiste na "falta de memória" (também chamada de memória markoviana) de um processo estocástico (Koski \& Noble, 2009). Esta propriedade garante que para a predição do estado seguinte do sistema matemático basta conhecer o estado atual, ou seja, os estados anteriores são irrelevantes. Um processo aleatório é uma coleção de variáveis aleatórias indexadas por um conjunto $I$, tomando valores de um conjunto $S$. I é o conjunto dos índices, geralmente tempo. $S$ é o espaço de estados, como $\{1,2,3, \ldots, n\},\{a, b, c\}, \mathbb{Z}^{+}, \mathbb{R}^{\mathrm{n}}$.

Podemos classificar o processo aleatório de acordo com o conjunto índice (discreto ou contínuo) e o espaço de estados (finito, contável ou incontável/infinito). Um processo aleatório é chamado de processo markoviano se, dado o estado atual, os 
estados futuros são independentes dos estados passados. Tomando como exemplo uma rede bayesiana simples como a representada na Figura 3, se tratada como uma cadeia de Markov, poderíamos observá-la na forma expandida como na Figura 4. Em casos em que a modelagem de uma rede bayesiana dinâmica está associada a variáveis contínuas e estados discretos é possível remodelar em uma cadeia de markov tempocontínuo.

$\mathrm{Na}$ forma desenrolada é fácil observar que, dado o estado em $t_{i}$, o estado em $t_{i+1}$ só depende de $t_{i}$. Note que todas as relações entre nós estão representadas na forma expandida entre duas unidades de tempo consecutivas.

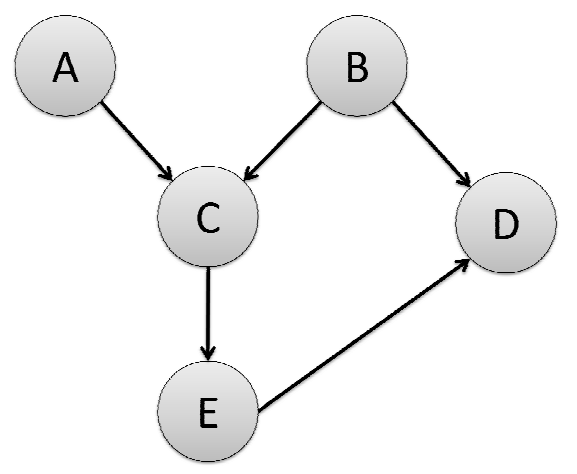

Figura 3 - Representação simplificada de uma rede bayesiana em grafo direcionado acíclico.

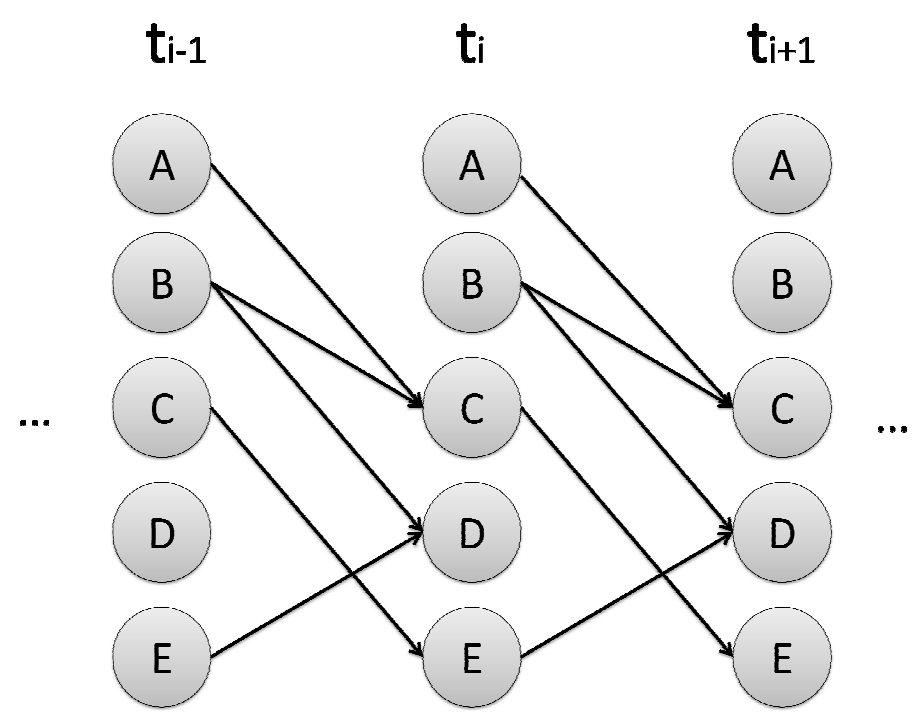

Figura 4 - Representação expandida (urolled) de um grafo direcionado acíclico, comumente utilizada para representar uma rede bayesiana dinâmica. Como as dependências não se alteram no tempo, esta pode também representar uma cadeia de Markov. 


\subsection{Repositórios Públicos em Larga Escala}

Antes de descrever o funcionamento da metodologia SIFTER é necessária a apresentação dos principais bancos de dados biológicos utilizados como fonte de informação para a metodologia.

\subsubsection{NCBI Taxonomy}

O NCBI Taxonomy é um dos grandes bancos de dados presentes nos repositórios do "National Center for Biotechnology Information" (http://www.ncbi.nlm.nih.gov/), que por sua vez é parte da "United States National Library of Medicine" (NLM), um ramo do "National Institutes of Health" (NIH) (Sayers et al., 2012). Este banco de dados surgiu em 1991, junto com a primeira versão do metabuscador Entrez (Federhen, 2012). Surgiu com a necessidade de uma nomenclatura e estrutura taxonômica comum a todos os registros indexados pelo Entrez e hoje é o padrão taxonômico de facto em uso pela comunidade científica. Originalmente surgiu como um thesaurus, mas está se formalizando uma ontologia e se alinhando aos padrões propostos pela OBO Foundry (http://obofoundry.org/; Smith et al, 2007). Em setembro de 2011 este banco de dados contava com 234.991 espécies com nomes formais e 405.546 espécies com nomes informais indexados (Federhen, 2012).

\subsubsection{UNIPROT}

O Universal Protein Resource (UniProt), é repositório centralizado e abrangente de sequências de proteínas com ampla cobertura e uma abordagem sistemática para anotação de proteínas, incorporação de sequências, interpretação e padronização de informações provindas de diversas fontes (Whitfield et al., 2006; The UniProt Consortium, 2012). É mantido pelo "The UniProt Consortium", uma colaboração entre o "Swiss Institute of Bioinformatics" (SIB), o "European Bioinformatics Institute" (EBI), e o "Protein Information Resource" (PIR). Este repositório libera uma nova versão de seu banco de dados a cada duas semanas. Em 22 de fevereiro de 2012 possuía informações de 534.635 sequências no UniprotKB/Swiss-Prot (manualmente anotadas 
e revisadas) e 20.127.441 sequências no UniprotKB/TrEMBL (automaticamente anotadas e não-revisadas) (http://www.uniprot.org/).

\subsubsection{Gene Ontology}

O projeto Gene Ontology (GO - http://www.geneontology.org), fundado em 1998, proporciona à comunidade científica informações padronizadas sobre produtos gênicos por meio de ontologias de domínio específico (Whitfield et al., 2006; du Plessis et al., 2011; The Gene Ontology Consortium, 2012). Este projeto consiste num esforço colaborativo para anotar produtos gênicos de acordo com três vocabulários estruturados, controlados e não-redundantes, descrevendo funções moleculares, localização subcelular e processos biológicos relacionados a produtos gênicos. Muitos bancos de dados biológicos adotaram a anotação padronizada do tipo GO, facilitando muito a integração de dados com outros grupos. O GO se tornou uma ontologia biológica de referência no campo da bioinformática, sendo considerada a mais importante ontologia associada ao "The Open Biomedical Ontologies (OBO) consortium" (Smith et al., 2007). O "Gene Ontology Consortium" libera atualizações mensais de seus bancos de dados e atualmente (fevereiro de 2012) possui 10222 códigos referentes a funções moleculares, 22763 referentes a processos biológicos e 3091 referentes à localização subcelular.

\subsubsection{Gene Ontology Annotation}

O projeto Gene Ontology Annotation (GOA) é uma combinação de mapeamentos eletrônicos e curadoria manual associando termos GO a todos os proteomas completos e incompletos existentes no Uniprot, baseados nos tipos de evidência propostos pelo projeto GO (Dimmer et al., 2011), amplamente utilizado pela comunidade científica. Atualmente o projeto GO prevê 21 tipos de evidência diferentes, distribuídos entre evidências experimentais, provindas de análise computacional, evidências declaradas por autor, evidências declaradas por curador e inferidos por anotação eletrônica (http://www.geneontology.org/GO.evidence.shtml, acessado em fevereiro de 2012). Dentre os 114.738 .016 registros no GOA, 113.803 .706 
registros (cerca de 99,2\%) correspondem ao grupo com maior número de registros de evidências, as inferidas por anotação eletrônica (versão 105, fevereiro de 2012).

\subsubsection{PFAM}

O banco de dados PFAM, elaborado pelo "Welcome Trust Sanger Institute", é o principal banco de dados de domínios e famílias de proteínas da atualidade (http://pfam.sanger.ac.uk; Sammut, 2008; Punta et al., 2012). Criado em 1995, tinha como propósito criar uma coleção de domínios de proteínas comuns para anotar as proteínas complexas de animais, mas atualmente é a classificação precisa e completa dos domínios e famílias de proteínas (Sammut, 2008). Cada família de proteínas é construída a partir de um alinhamento "semente", com representantes importantes da família (Punta et al., 2012). O alinhamento "semente" é utilizado para criar um perfil da família de proteínas através do programa HMMER3 (http://hmmer.janelia.org; Eddy, 2008), e este perfil é utilizado para detectar outros membros da família. O Pfam é composto de dois bancos principais, o Pfam-A, baseado no Uniprot, altamente curado e de alta qualidade; e o Pfam-B, baseado no bando de dados ProDom, gerado automaticamente pelo algoritmo ADDA e com as regiões em comum com o Pfam-A retiradas (Punta et al., 2012). A última versão do seu banco de dados (v27.0) possui 14.831 famílias (http://pfam.sanger.ac.uk).

\subsection{Metodologia SIFTER}

Com o advento das tecnologias mais recentes de seqüenciamento o volume de informações genômicas cresceu em um ritmo acelerado, velocidade muito superior à da anotação experimental destas sequências. Como a utilidade de genes não-anotados ou mal anotados é limitada, existe um grande esforço da comunidade científica para o desenvolvimento de ferramentas computacionais eficientes para a anotação e reanotação de genomas inteiros, garantindo bons insights sobre os dados obtidos computacionalmente (van den Berg et al., 2010). Bons resultados estão sendo obtidos ao incorporar a abordagem filogenômica às ferramentas, e atualmente a ferramenta 
mais bem sucedida neste campo é a ferramenta SIFTER (Engelhardt et al., 2005; Engelhardt et al., 2006; Engelhardt et al., 2011).

A metodologia SIFTER, acrônimo para Statistical Inference of Function Through Evolutionary Relationships, é um poderoso método se comparado a outras metodologias de anotação funcional de proteínas, entretanto a metodologia ainda não foi aplicada em escala genômica (Conte et al., 2008; Engelhardt et al., 2005; Engelhardt et al., 2006; Engelhardt et al., 2011).

O SIFTER faz uso da abordagem filogenômica, mais eficiente para a anotação do que outras metodologias, e modela sobre a estrutura de uma rede bayesiana (Engelhardt et al., 2005; Engelhardt et al., 2006). Desta forma, o software é capaz de aproveitar anotações de qualidade, combiná-las de acordo com as relações filogenéticas e determinar a função candidata de maior probabilidade entre proteínas homólogas (Heckerman, 1995; Engelhardt et al., 2005; Engelhardt et al., 2006).

A partir da idéia de que a função molecular evolui com a sequência (Sjölander, 2004), a filogenômica é capaz de melhorar a qualidade da predição da função (Engelhardt et al., 2005). A filogenômica, se aplicada manualmente, é uma metodologia que necessita de grande esforço de um especialista da área; a qualidade da anotação depende da perícia do especialista e da qualidade das anotações disponíveis; e podem surgir complicações da possível escassez ou conflito de informações disponíveis. Estas dificuldades incentivaram o uso da metodologia estatística para a modelagem filogenômica (Engelhardt et al., 2005).

De acordo com o modelo, cada função evolui de uma função ancestral. Proteínas que sofreram duplicação evoluem mais rapidamente que proteínas que sofreram eventos de especiação (Engelhardt et al., 2005). O evento de duplicação reduz a pressão seletiva sobre a cópia sobressalente, aumentando a taxa de mutações que persiste no descendente (Engelhardt et al., 2006).

A abordagem bayesiana é bem apropriada para este tipo de análise porque ela explora todas as observações, o que é importante para informações esparsas 
(Engelhardt et al., 2005). Além disso, ela é resistente a erros nos dados (Heckerman, 1995; Engelhardt et al., 2005). Esta é uma característica essencial para o modelo, tanto pela qualidade das informações anotadas, quanto pela qualidade da árvore reconstruída, que muitas vezes não reflete de forma eficaz a história evolutiva (Engelhardt et al., 2005). Na última versão (v2.0), com intuito de acelerar o cálculo das probabilidades, a rede bayesiana é remodelada em uma cadeia de Markov tempo contínuo, permitindo sua aplicação em escalas maiores, sem redução significativa de qualidade (Engelhardt et al., 2011).

O modelo probabilístico de como as funções moleculares evoluem leva em conta evidências de qualidades variáveis e computa a probabilidade posterior de cada função molecular, de acordo com os termos de função molecular do Gene Ontology (http://www.geneontology.org/) para cada proteína na filogenia, incluindo as ancestrais (Engelhardt et al., 2005).

As anotações observadas para as folhas são propagadas para a raiz e propagadas de volta para as folhas, baseado em um conjunto de equações de atualização de probabilidade definido pelo modelo de evolução proposto. O resultado é uma probabilidade a posteriori de cada função molecular para cada nó na árvore, condicionada pelas funções observadas (Figura 5). Portanto, as probabilidades posteriores não selecionam uma única função para cada nó (Engelhardt et al., 2005).

Nesta metodologia, a partir de uma proteína, é determinada a família de proteína relacionada ao domínio similar segundo o banco de dados PFAM, e retiramos o alinhamento múltiplo desta família de proteínas de outro arquivo do banco de dados PFAM (Finn et al., 2010; http://pfam.sanger.ac.uk/) (Engelhardt et al., 2005). A partir do alinhamento, é construída uma árvore filogenética. É importante lembrar que, devido ao modelo bayesiano, árvores de baixa qualidade não reduzem 

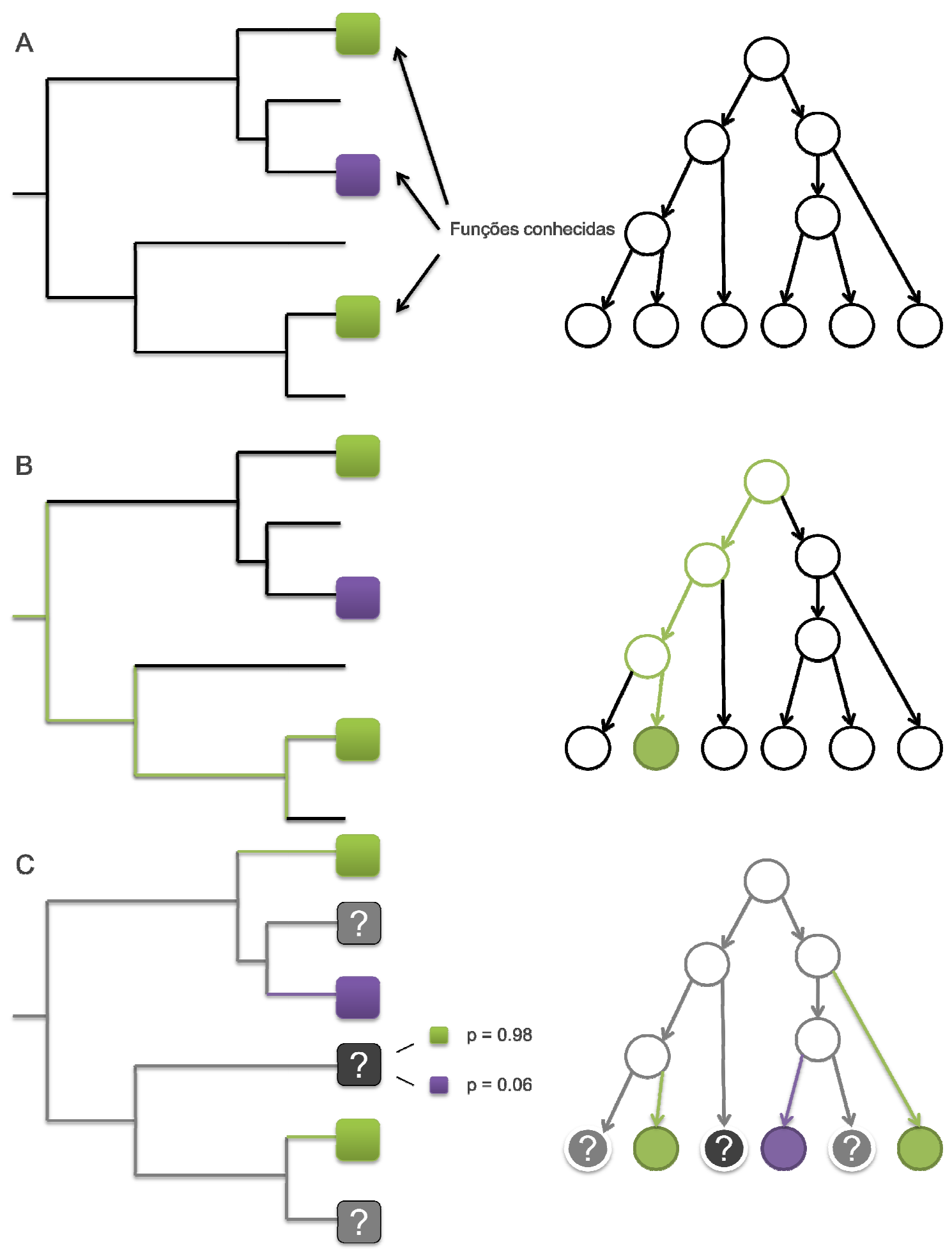

Figura 5 - Representação simplificada dos principais passos envolvidos na anotação funcional pela metodologia SIFTER. À esquerda, representação de uma árvore de genes, à direita, a rede bayesiana equivalente. A - Uma rede bayesiana é construída partir de uma árvore de genes e as funções conhecidas são associadas aos respectivos genes. B - As probabilidades das funções conhecidas são propagadas à raiz da rede bayesiana. C - As probabilidades da raiz são então propagadas aos genes sem anotação conhecida, gerando uma lista de funções propagadas e suas respectivas probabilidades para cada gene. 
significantemente a qualidade dos resultados (Heckerman, 1995; Engelhardt et al., 2005). A árvore passa pelo processo de reconciliação, gerando uma árvore enraizada com comprimentos de ramos e eventos de duplicação anotados nos nós internos (Engelhardt et al., 2005).

\subsection{Modelo matemático de propagação}

Para compreender o método e suas implicações é necessário o entendimento das bases matemáticas da metodologia, que tem como estrutura básica as redes bayesianas. Considerando como descrita a estrutura básica de uma rede bayesiana no item 2.2 e o funcionamento básico da metodologia SIFTER no item 2.4, explicitarei neste item somente a estatística envolvida na atualização das probabilidades para cada nó da rede.

A partir de uma família PFAM, as informações anotadas (Gene Ontology Annotation - GOA) são recuperadas para cada gene na família de proteínas. A árvore reconciliada de genes fornece a estrutura em que as funções são propagadas de um nó com anotações para um nó sem anotações. Neste processo cada nó é associado a vetores de funções anotadas e a função de propagação é aplicada (Figura 5). Com isso, obtemos o vetor de probabilidades para cada nó ou folha da árvore, inclusive a sequência a ser consultada (Engelhardt et al., 2005). A versão 2.0 do motor de inferência SIFTER (Engelhardt et. al., 2011) modela a propagação de funções na árvore utilizando uma Cadeia de Markov de primeira ordem, uma forma muito utilizada para modelar redes Bayesianas dinâmicas, pois possui custo computacional inferior.

Segundo Engelhardt et al. (2011), sendo $X_{i}$ um vetor boleano de anotações de funções candidatas para o nó (proteína) i; $M$ o número de componentes deste vetor (número de funções candidatas); $N$ o número de proteínas nas folhas; $\sigma_{\text {spe }}$ e $\sigma_{d u p}$ a escala de tempo após um evento de especiação ou duplicação respectivamente; $\propto=\left\{\propto_{1}, \ldots, \propto_{M}\right\}$ o vetor de parâmetros que descreve a taxa de surgimentos espontâneos de funções; e a matriz de parâmetros $\Phi=\left\{\phi_{11}, \phi_{21}, \ldots, \phi_{M M}\right\}$ a taxa de mutação e perda de função (Figura 6). Na matriz de parâmetros os elementos da 
diagonal principal representam a taxa de desaparecimento de funções e os restantes representam a taxa de mudança de função $i$ para uma função $j$.

Com os parâmetros $\Phi$ e $\propto$ é possível construir a matriz de transição $Q$, que descreve a mudança de estados de atividade funcional entre os ancestrais e seus descendentes. Para seu cálculo consideramos que suas linhas representam os estados parentais, suas colunas os estados filhos, seus valores somam no máximo $M, \propto$ está limitado ao M-ésimo simplex e os parâmetros são não-zero para evitar estados inalcançáveis ou atratores. Dada uma configuração parental, a probabilidade condicional de certa configuração nos nós filhos segue a equação:

$$
p\left(X_{i}=s_{j} \mid X_{\pi i}=s_{k}, t_{i}, \Phi, \sigma, \alpha\right)=\left\{\exp \left(t_{i} \sigma Q\right)\right\}_{k, j}
$$

$X_{i}$ representa a configuração de funções no nó filho, $X_{\pi i}$ representa a configuração de funções no nó parental imediato, $t_{i}$ representa o comprimento do ramo que separa estes nós, $j$ e $k$ índices do conjunto potência $S, s_{j}$ e $s_{j} \in S$, e $\exp$ é a matriz função exponencial $\exp (t \sigma Q)=\sum_{k=0}^{\infty} \frac{(t \sigma Q)^{k}}{k !}$. Esta matriz representa a probabilidade de uma proteína no estado $k$ mudar para o estado $j$ após o tempo $t_{i}$, que representa o comprimento do ramo na árvore. A probabilidade conjunta desta árvore pode ser calculada pela função:

$$
p(X \mid \Phi, \sigma, \alpha)=p\left(X_{\text {root }}\right) \prod_{i \in \text { tree }} p\left(X_{i} \mid X_{\pi i}, t_{i}, \Phi, \sigma, \alpha\right)
$$

Os parâmetros deste modelo podem ser estimados pelo algoritmo estimaçãomaximização generalizado (generalized expectation maximization - GEM) (Gelman et al., 2003).

Por fim, o modelo matemático aproveita probabilisticamente todas as anotações nas folhas da rede bayesiana ponderando a priori de confiabilidade por tipo de evidência segundo a tabela 1. 


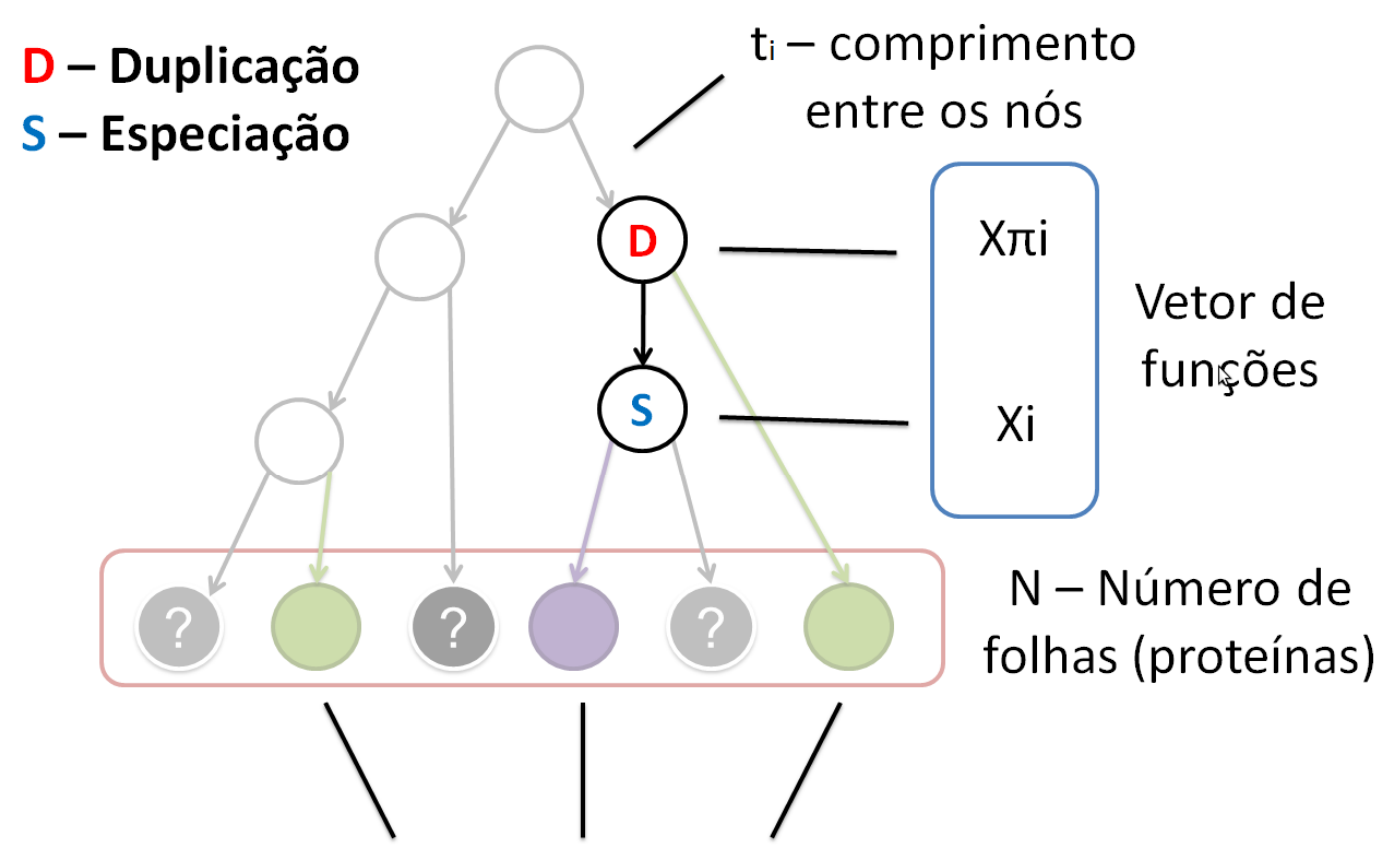

M - Número de funções anotadas

Figura 6 - Ilustração dos principais elementos utilizados pelo Sifter na propagação das probabilidades de funções através de uma árvore de genes (engelhardt et al., 2011).

Tabela 1 - Códigos de evidência do Gene Ontology (The Gene Ontology Consortium, 2011), e probabilidades de correção correspondentes no SIFTER. As probabilidades foram determinadas por um especialista. (Engelhardt, 2007)

\begin{tabular}{ccc}
\hline $\begin{array}{c}\text { Código de } \\
\text { Evidência }\end{array}$ & Nome completo (original) & $\begin{array}{c}\text { Probabilidade } \\
\text { a priori }\end{array}$ \\
\hline IDA & Inferred by direct assay & 0.9 \\
TAS & Traceable author statement & 0.9 \\
IMP & Inferred by mutant phenotype & 0.8 \\
IGI & Inferred from genetic interaction & 0.8 \\
IPI & Inferred from physical interaction & 0.8 \\
ISS & Inferred by sequence or structural similarity & 0.4 \\
RCA & Inferred from reviewed computational analysis & 0.4 \\
IGC & Inferred from genetic interaction & 0.4 \\
IEP & Inferred from expression pattern & 0.4 \\
IC & Inferred by curator & 0.4 \\
NR & Not recorded & 0.3 \\
NAS & Non-traceable author statement & 0.3 \\
ND & No biological data available & 0.3 \\
IEA & Inferred by electronic annotation & 0.2
\end{tabular}


Segundo Engelhardt et. al. (2011) o motor de inferência SIFTER, em sua versão 2.0 possui complexidade $\mathrm{O}\left(\mathrm{N}\left(\left(2^{\mathrm{M}}\right)^{2^{*} 3}\right)\right)$, sendo linear em relação ao tamanho da árvore "N" e exponencial em relação ao número de funções moleculares possíveis " $M$ ". Isto torna possível a aplicação em grandes famílias de proteínas, entretanto limita em relação ao número de funções candidatas para cada família de proteínas estudada (Engelhardt et al. 2006). 


\section{Capítulo 3 \\ ESTUDO DA IMPLEMENTAÇÃO ORIGINAL E LEVANTAMENTO DE REQUISITOS}

Neste capítulo a implementação original da metodologia Sifter será analisada em maiores detalhes (seção 3.1) e em seguida serão levantadas questões a serem tratadas para que a metodologia Sifter seja facilmente aplicável (seção 3.2). Para simplificar o entendimento deste ponto em diante tratarei a fase de pré e pósprocessamento dos dados e todos os componentes relacionados de "workflow SIFTER"; e o componente de inferência probabilística das funções dos genes de "motor de inferência SIFTER". Todos os estudos e análises são referentes à versão 2.0 da metodologia SIFTER (Engelhardt et al., 2011).

\subsection{Estudo da implementação da metodologia SIFTER}

O motor de inferência SIFTER consiste em um conjunto de classes escrito em linguagem de programação Java (http://www.java.com/). Acompanhando o software, existem dois conjuntos de scripts de preparação dos arquivos de entrada no SIFTER. $O$ primeiro deles, escrito em linguagem de programação Perl (http://www.perl.org/), uma linguagem muito flexível, multiplataforma, com bons recursos de manipulação de texto. O segundo conjunto foi escrito em Python (http://www.python.org/), que possui, além das principais características de Perl, código mais organizado, simples e de desenvolvimento mais rápido. Toda a descrição e desenvolvimento a seguir se referem ao segundo conjunto de scripts, desenvolvido em linguagem Python.

\subsubsection{Workflow original}

Os scripts que compõem o workflow SIFTER são "pull_alignments.py", "clean_tree.py", "pfam2sifter.py" e "run_hundred_families.py" e dependem de BioPython (Cock et al., 2009; http://biopython.org/) para o funcionamento correto. 0 
fluxo de dados está organizado resumidamente como a figura 7. O motor de inferência SIFTER precisa de dois arquivos de entrada: Um contendo uma árvore de genes, o outro contendo o mapeamento das anotações conhecidas para os genes desta árvore. Os scripts fornecidos com o motor de inferência são simples, mas suficientes para a geração destes arquivos.

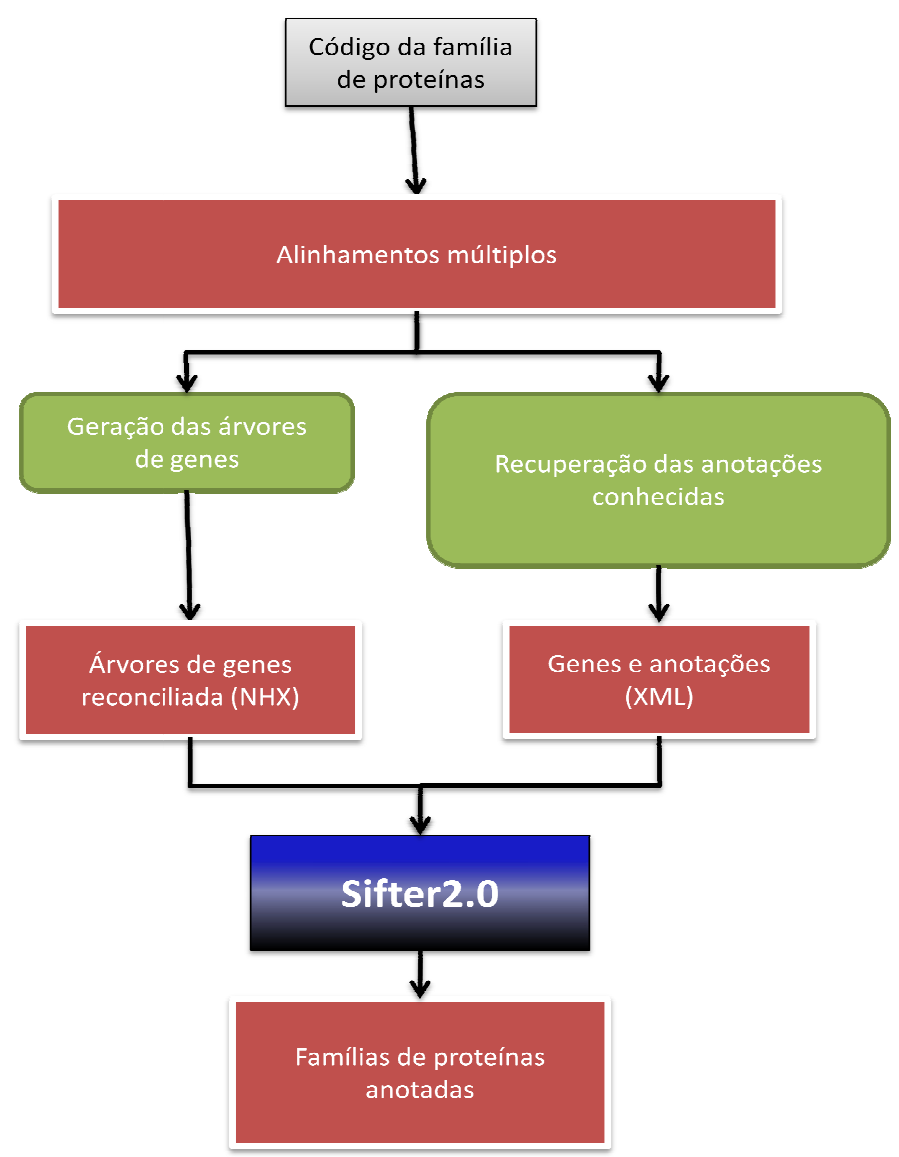

Figura 7 - Workflow SIFTER original. Cinza - dados de entrada; Verde - principais módulos de processamento; Vermelho - Arquivos de saída do workflow SIFTER; Azul/preto - Motor de inferência SIFTER.

Cada script inicialmente lê um arquivo contendo uma lista de famílias de proteínas a serem analisadas. Neste arquivo, as famílias de proteínas encontram-se no formato padrão do PFAM, que começa com PF (acrônimo de "protein family") seguido de 5 números, identificando a família. Por ex: "PF00002". Esta lista pode estar separada por espaço, tabulação ou nova linha.

O script "pull_alignments.py", realiza a recuperação do alinhamento múltiplo para as famílias de proteínas de entrada e em seguida gera a árvore a partir deste alinhamento. A partir de um arquivo contendo a lista de famílias de proteínas, como já 
descrito, recupera informações do arquivo "Pfam-A.full" (Finn et al., 2010), gerando arquivos em formato "Stockholm" (especificações em http://sonnhammer.sbc.su.se/Stockholm.html), um formato de alinhamento múltiplo utilizado pelos bancos de dados PFAM. Este arquivo, que contém alinhamentos múltiplos para as proteínas de uma mesma família, é então convertido para o formato "fasta" (descrição em http://www.ncbi.nlm.nih.gov/blast/fasta.shtml), um formato popular de sequências. Esta conversão necessita de um script de terceiros, chamado "convalign.py". O arquivo fasta, contendo o alinhamento múltiplo de todas as proteínas de uma mesma família de proteínas, é utilizado para gerar uma árvore de genes por meio do programa FastTree (Price et al., 2009; Price et al., 2010; http://www.microbesonline.org/fasttree/), que utiliza um método heurístico variante de Neighbour Joining para gerar a árvore. A árvore é gerada em formato Nexus (Maddison et al., 1997). O script "clean_tree.py" atua na conversão dos arquivos em formato "Nexus" para o formato "New Hampshire eXtended" (especificações em http://www.phylosoft.org/NHX/), formato de entrada do SIFTER (passo não representado na figura 7).

O script "pfam2sifter.py" percorre o arquivo "Pfam-A.fasta" (Finn et al., 2010) para recuperar a lista de genes que estão associados às famílias de proteínas. Em seguida o script percorre o arquivo "gene_association.goa_uniprot" (ftp://ftp.ebi.ac.uk/pub/databases/GO/goa/UNIPROT/gene association.goa uniprot.gz), recupera as anotações do tipo funcional, com códigos de evidência entre os parâmetros de entrada, para todos os genes das famílias de proteína selecionadas. Por fim, estas informações são combinadas em uma estrutura no formato XML (eXtensible Markup Language), formato de entrada para o software SIFTER. Este arquivo formato XML, com extensão “.pli”, contém as informações de anotação de todos os genes relacionados para uma mesma família de proteína e suas anotações, quando presentes. $\mathrm{O}$ arquivo possui a estrutura exemplificada na figura 8.

O último script, "run_hundred_families.py" automatiza a execução do motor de inferência SIFTER para cada família de proteínas. Para cada família de proteínas da lista de famílias de proteínas o script executa o motor de inferência SIFTER uma primeira vez com a opção "--generate", que se utiliza das informações dos arquivos ".pli" e 
".nhx" para gerar, para cada família, 3 arquivos: "infer-pf*****.fx", "scale-pf*****.fx" e "alpha-pf*****.fx". O arquivo "scale-pf*****.fx" contém as taxas de evolução associadas aos eventos de duplicação e especiação, iniciados por padrão com 0.05 e 0.03 respectivamente (Engelhardt et al., 2006). Estes valores podem ser alterados de acordo com as necessidades de cada análise. O arquivo "infer-pf*****.fx" contém uma matriz de transição de parâmetros, com cada linha e cada coluna representando uma função candidata.

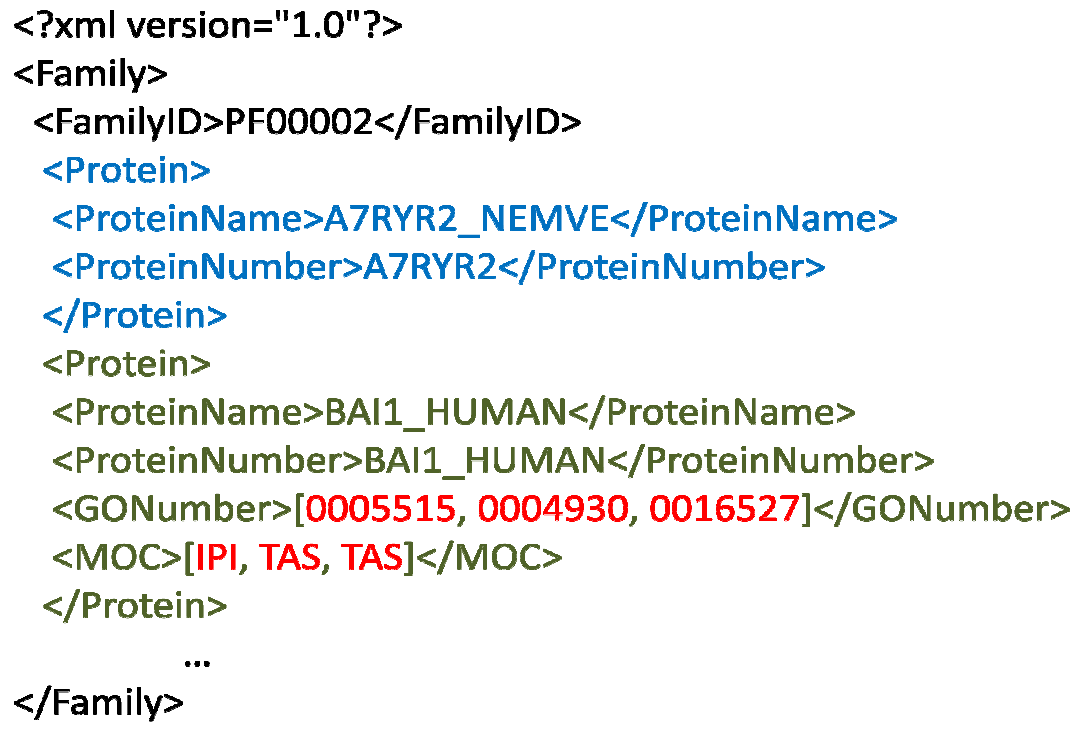

Figura 8 - Exemplo da estrutura dos arquivos ".pli" gerados ao final do script "pfam2sifter.py". Em azul, exemplo de proteína sem anotação; em verde, exemplo de proteína com anotação; em vermelho, exemplo de anotação para a proteína BAI1_HUMAN, com anotações funcionais do tipo IPI (Inferred from physical interaction) e TAS (Traceable author statement).

Em seguida o script recupera o número de funções candidatas de "alpha$\mathrm{pf}^{* * * * *} . \mathrm{fx}^{\prime \prime}$. Segundo o padrão do script, este valor precisa ser um valor de 2 a 7. Considerando que Engelhardt (2011) afirma que a complexidade computacional do SIFTER é $\mathrm{O}\left(\mathrm{N}\left(2^{\mathrm{M}}\right)^{2 \cdot 3}\right)$, sendo $\mathrm{N}$ o número de genes na família de proteínas e $\mathrm{M}$ o número de funções candidatas, sendo estes os limites da aplicação do motor de inferência SIFTER na anotação em larga escala.

Se o número de funções candidatas for respeitado, o próximo passo é a anotação propriamente dita. O motor de inferência SIFTER é executado novamente, utilizando os arquivos de entrada "PF*****.pli", do qual ele recupera as informações de anotação; "PF*****.nhx", a árvore pela qual serão propagadas as anotações; "infer- 
$\mathrm{pf}^{* * * * *} . \mathrm{fx}^{\prime}$, "scale-pf*****.fx" e "alpha-pf*****.fx", com os parâmetros de uso do SIFTER. Os arquivos gerados ao final do processo são "PF*****-sifterout.txt", que contém a saída para o monitor da execução do SIFTER; e PF*****.rdata", que contém as informações de anotação probabilística. O formato de saída é:

$<$ NODE NAME $><$ POSTERIOR FN1 $>\ldots$ <POSTERIOR FNm $><$ MAX POSTERIOR PREDICTION $>$

Como por exemplo:

$\begin{array}{llllll}\text { calcr_pig } & 0.9960239633105679 & 0.07628977950793243 & 0.07950043523590085 & 4948\end{array}$ q8cabo_mouse $0.9819255688728563 \quad 0.15671589849437728 \quad 0.15943461283254143 \quad 4948$

Neste exemplo temos "calcr_pig" e "q8cab0_mouse" como os nomes dos nós, para cada uma temos as probabilidades a posteriori de três funções candidatas e no final a função candidata de maior probabilidade, que possui o termo do Gene Ontology de número 4948. Se buscarmos a informação relacionada a este termo no Gene Ontology Database, obtemos a associação com "calcitonin receptor activity".

\subsubsection{Motor de Inferência}

O motor de inferência SIFTER, escrito em linguagem de programação Java, possui duas classes centrais, "PFun" e "PFunLibrary", e o restante está organizado em dois pacotes: O pacote "Util", que possui as estruturas para que ocorram as propagações, as funções de saída na tela e manipulação de arquivos; e o pacote "Stat", que possui as classes necessárias para o cálculo e propagação das probabilidades ao longo da árvore (Figura 9). 


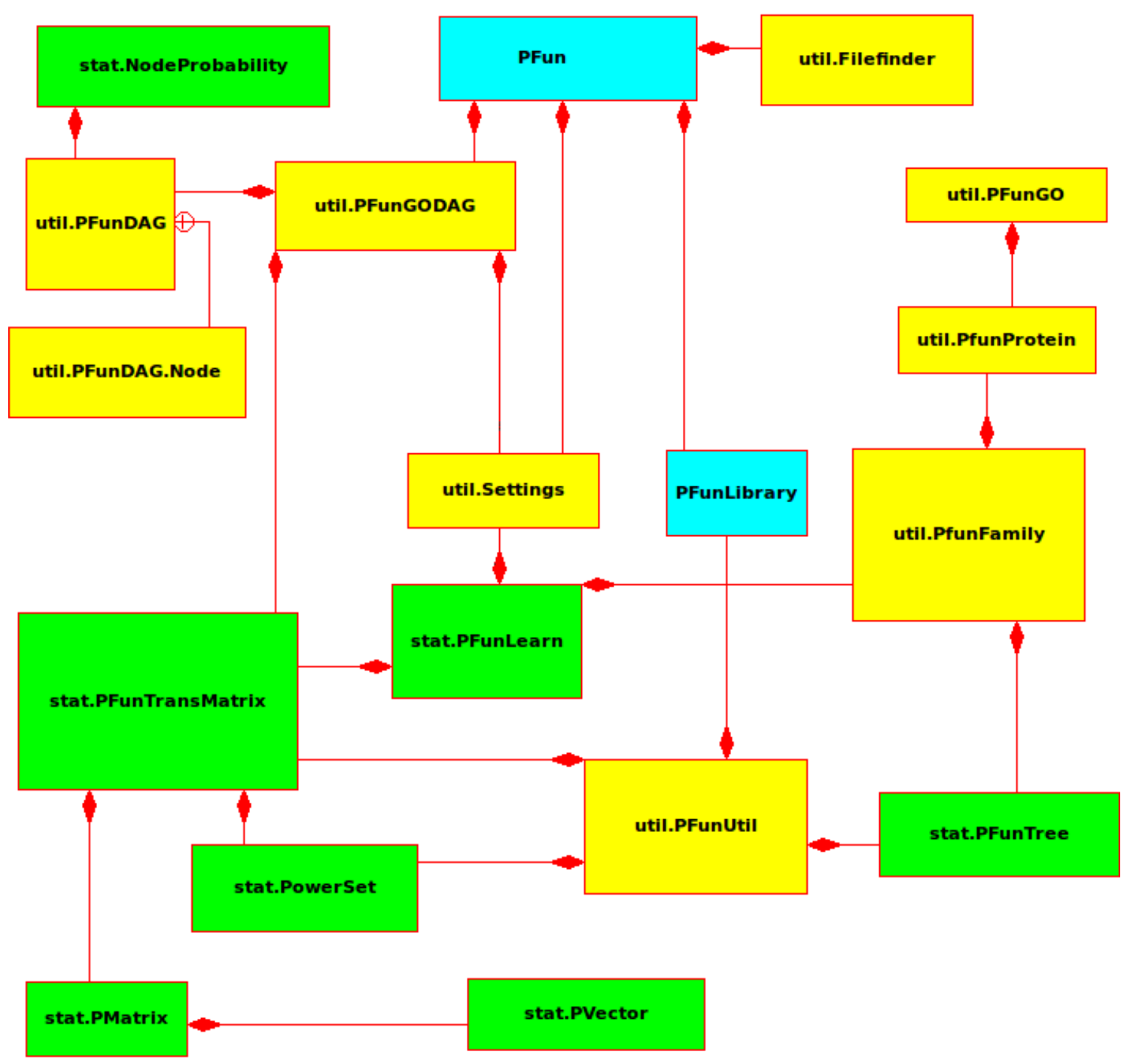

Figura 9 - Diagrama de classes para o motor de inferência SIFTER. Verde - Classes pertencentes ao pacote "stat"; Amarelo - Classes pertencentes ao pacote "util"; Azul - Classes

O estudo das classes foi suficiente para detectar questões que devem ser tratadas para que o motor de inferência SIFTER seja capaz de lidar com os novos bancos de dados e com maior eficiência de anotação. 


\subsection{Levantamento das questões passíveis de tratamento}

Em linhas gerais os scripts do workflow Sifter são procedurais, com severas limitações no aproveitamento das estruturas de dados de python, sem documentação para orientar o desenvolvedor, com documentação muito pobre e confusa para o usuário final, em vários passos o pesquisador é obrigado a conhecer a linguagem de programação e alterar parâmetros manualmente, além do conjunto de scripts ser incompleto em relação à metodologia proposta nas publicações (não possui ferramenta ou documentação que auxilie na elaboração das árvores de espécies ou processo de reconciliação). O motor de inferência Sifter (escrito em Java), por outro lado, possui estrutura complexa, orientada a objetos, com certa orientação para o desenvolvedor. Apesar do código melhor elaborado nós encontramos bugs na atribuição das probabilidades a priori para os códigos de evidência IGC e IGI (arquivo "PFunGODAG.java”).

Estudando as condições gerais da implementação atual conseguimos identificar várias questões que careciam de aperfeiçoamento. Algumas são mandatórias, como a adaptação do workflow aos bancos de dados biológicos mais atuais; outras são muito importantes para que os pesquisadores possam utilizar a anotação Sifter de forma adequada e em larga escala. A seguir trataremos dos principais itens encontrados.

\subsubsection{Bancos de dados biológicos}

A adaptação da metodologia aos novos formatos de bancos de dados biológicos é essencial para que a metodologia não seja limitada pela última versão dos bancos de dados nos formatos aceitos. A seguir são apresentadas as principais adaptações realizadas.

\subsubsection{Formato do arquivo das ontologias funcionais}

Para a propagação das anotações entre os nós a metodologia SIFTER se utiliza da estrutura hierárquica da ontologia funcional do Gene Ontology, em formato "GO Flat File". O banco de dados Gene Ontology em 2006 alterou definitivamente o formato de saída de sua ontologia de "GO Flat File" para o formato "OBO", com o intuito de se alinhar aos padrões de ontologia biológica propostos pelo "The Open 
Biological and Biomedical Ontologies" (OBO Foundry). Como o motor de inferência SIFTER ainda não está preparado para utilizar as versões mais recentes deste banco de dados, elaboramos estratégias para sanar esta deficiência.

\subsubsection{Tipos de evidência}

O Gene Ontology sofre atualizações constantes em sua estrutura. Em dois momentos distintos (abril/2008 e maio/2011) o consórcio incluiu novos códigos de evidência padronizados para as anotações baseadas no Gene Ontology (http://www.geneontology.org/GO.evidence.shtml). São os códigos ISA (Inferred from Sequence Alignment), ISO (Inferred from Sequence Orthology) e ISM (Inferred from Sequence Model) adicionados em 2008; e os códigos IBA (Inferred from Biological aspect of Ancestor), IBD (Inferred from Biological aspect of Descendent), IKR (Inferred from Key Residues) e IRD (Inferred from Rapid Divergence), adicionados em 2011. Os códigos IKR e IRD são considerados não-anotação por caracterizarem anotações recorrentemente mal interpretadas. IBA e IBD, entretanto, caracterizam anotações relativas à transferência de anotação por relações taxonômicas de ascendência ou descendência muito próximas; e os códigos ISA, ISO e ISM são derivados do código ISS (Inferred from Sequence or Structural Similarity). Como são recentes, estes códigos ainda não são aproveitados pelo motor de inferência SIFTER. Segundo Engelhardt (2007), as probabilidades a priori para os tipos distintos de evidências foram definidas por especialista. Buscamos então estratégias para incluir estes códigos de evidência na propagação pela metodologia SIFTER.

\subsubsection{Reconstrução de Árvores de Genes e Árvores de Espécies}

O motor de inferência SIFTER foi projetado para utilizar informações de eventos de duplicação e especiação genética ao propagar as informações de anotação pela árvore de genes, resultando em maior qualidade de anotação. Estas informações são recuperadas de árvores reconciliadas de genes, como descrito no item 2.1. Para gerar a árvore reconciliada são necessárias a árvore de espécies, possuindo todas as espécies associadas aos genes, e uma árvore de genes com a indicação de espécie para cada gene. Os scripts originais de SIFTER estavam preparados para aproveitar as árvores de espécies que eram fornecidas em conjunto com os alinhamentos do PFAM. Entretanto, 
desde o lançamento da versão 23 de seu banco de dados, o PFAM não fornece as árvores de espécies para suas famílias de proteínas dentre seus arquivos. Além disso, os scripts não previam a preparação das árvores de espécies ou a reconciliação. A ausência da árvore de espécies implica na impossibilidade de realizar o processo de reconciliação, reduzindo significativamente a qualidade das anotações por meio da metodologia Sifter. Assim, para utilizarmos as informações de duplicação e especiação gênica, precisávamos elaborar uma estratégia para construir a árvore de espécies automaticamente e, em seguida, automatizar a reconciliação da árvore de genes e árvore de espécies para cada família de proteínas.

\subsubsection{Design Centrado no Usuário}

É conhecido que muitos softwares na área da bioinformática deixam de ser utilizados por sua precária usabilidade (Veretnik et al., 2008). Mesmo ferramentas conhecidas por sua qualidade na execução de uma tarefa são abandonadas em favor de ferramentas mais simples de usar, de instalar ou mais rápidas. Visando solucionar esta questão alguns grupos incentivaram e propuseram estratégias para o desenvolvimento centrado no usuário (Veretnik et al., 2008; Bolchini et al., 2009; Pavelin et al., 2012; de Matos et al., 2013). Baseado nas idéias propostas por Pavelin et al. (2012) e de Mattos et al. (2013) elaboramos uma metodologia para tornar a anotação funcional probabilística de Sifter acessível a pesquisadores com níveis diversos de conhecimento de bioinformática, e a desenvolvedores interessados em aperfeiçoar esta implementação.

Por meio de reuniões informais com estudantes das áreas biológica, de computação e de bioinformática estabelecemos que a principal audiência para o Sifter são cientistas da área biológica com conhecimentos básicos no uso de ferramentas de bioinformática e interessados principalmente na anotação funcional de seu próprio conjunto de genes. Com a ajuda do mesmo grupo foram levantados as principais deficiências da implementação Sifter em relação à interação com o usuário e as estratégias para solucioná-las. 


\subsubsection{Tipo de dados de entrada}

Uma questão importante a ser tratada no workflow SIFTER original era o tipo de dado de entrada aceito, uma lista simples de famílias de proteínas. Os genes presentes em uma família de proteína podem não representar perfeitamente o gene de interesse, gerando inconsistências na predição e dificultando a análise dos dados. Para que a utilização da metodologia SIFTER seja mais objetiva, facilitada e de maior qualidade, chegamos à conclusão de que a melhor forma de incorporar o gene de interesse seria reconhecer a que família de proteínas o gene faz parte e incorporar sua sequência ao alinhamento múltiplo de sua família de proteína. Assim o motor de inferência pode gerar anotações para a própria sequência e não uma similar. Para isso buscamos uma abordagem genérica para o reconhecimento das regiões de interesse a partir de sequências de nucleotídeos ou aminoácidos, capazes de lidar com qualquer táxon, regiões codificantes ou não, e de forma automática.

Após a descoberta automatizada das regiões das sequências de entrada associadas às famílias de proteína, é necessário incorporar estas sequências ao alinhamento múltiplo da família de proteínas fornecido pelo banco de dados PFAM. Para isso, estudamos as ferramentas de alinhamento múltiplo disponíveis na literatura e selecionamos ferramentas adequadas ao workflow SIFTER. Em seguida realizamos a perfilagem desta ferramenta para detectar possíveis questões a serem enfrentadas ao aplicá-la em larga escala.

\subsubsection{Estrutura do arquivo de saída}

O formato de saída dos dados é crucial para a interpretação dos dados pelo usuário final, determinando o tempo necessário para a compreensão do resultado e a qualidade das análises posteriores. Como foi observado no item 3.1.1, o formato do arquivo de saída do motor de inferência Sifter não favorece a interpretação dos dados pelo pesquisador, somente apontando o código para a função de maior probabilidade para cada gene. Para atacar esta questão pretendemos ao final gerar arquivos de mais fácil interpretação pelo pesquisador e de mais fácil manipulação pelas ferramentas tradicionais de tratamento de texto. 


\subsubsection{Dificuldade no uso da ferramenta e documentação}

Foi proposto a uma dupla de estudantes da área de bioinformática que tentassem, sem auxílio, utilizar a ferramenta a metodologia Sifter. As principais queixas foram a documentação limitada, confusa e desatualizada, incapaz de guiar de maneira satisfatória o pesquisador na anotação de seus genes; a necessidade de alterar manualmente o código do workflow em cada tentativa de execução; e a necessidade de compreensão significativa da implementação do workflow para que seja possível concluir todos os passos da anotação. Para solucionar estas questões pretendemos gerar um workflow integrado e automatizado, de uso mais intuitivo, com entrada de parâmetros facilitada e melhor documentado. Visando auxiliar o desenvolvedor, em conjunto com as alterações anteriores o workflow será reescrito de forma modular e seguindo o PEP8 (Style Guide for Python Code http://www.python.org/dev/peps/pep-0008/) com o intuito de aumentar a reusabilidade do código.

\subsubsection{Uso em larga escala}

Para alcançar o uso em larga escala da anotação pela metodologia SIFTER, a utilização dos recursos da máquina é uma questão muito importante a ser tratada. Em uma análise preliminar ficou claro que o workflow original carecia de otimizações, possuindo gargalos de input/output (IO); gargalos de processamento por mau aproveitamento dos recursos e estruturas de dados nativos em python e que ao longo de todo o código utilizava somente um núcleo; além de muitos trechos de computação redundante. Sem estas otimizações a escalabilidade da metodologia é pequena, não sendo suficiente para a resolução das anotações de um genoma inteiro em tempo hábil. 


\section{Capítulo 4 Metodologia e Resultados - WorkFLOW}

Ao longo dos capítulos 4 e 5 serão apresentadas as principais alterações do workflow Sifter em relação à implementação original. O capítulo 4 vai ressaltar as alterações relativas ao fluxo de dados e novos módulos e o capítulo 5 vai destacar as alterações relativas ao aperfeiçoamento do tempo de execução e aproveitamento de memória.

O workflow final foi dividido em duas fases. A primeira, executada somente uma vez, concentra a preparação dos arquivos a partir dos arquivos da ontologia Gene Ontology, das anotações do Gene Ontology Annotation, das relações taxonômicas do NCBI Taxonomy e das famílias de proteínas do PFam. A segunda fase é a execução da anotação do conjunto de dados de entrada.

No item 4.1 serão apresentadas as alterações necessárias para que o workflow pudesse se aproveitar eficientemente das versões mais recentes dos bancos de dados biológicos; no item 4.2 serão apresentadas as principais alterações relativas à usabilidade da ferramenta; e no item 4.3 será apresentada uma visão global do workflow resultante.

\subsection{Bancos de dados biológicos}

\subsubsection{Formato do arquivo das ontologias funcionais}

A ferramenta "obo2flat", do "OBO-Edit 2.2" (http://oboedit.org/) é uma ferramenta que em sua proposta é capaz de facilmente converter os formatos atuais de arquivo do Gene Ontology para o formato "GO Flat File". Contudo na prática a ferramenta apresenta muitas dificuldades nesta conversão, apresentando vários erros que impedem a conclusão da conversãoe a geração de arquivos compatíveis e, portanto, a aplicação de forma automática. Optamos então por converter o arquivo em formato OBO por meio de script próprio. 
Criamos uma classe de conversão (linguagem Python) que realiza o parseamento de cada nó da ontologia funcional do Gene Ontology e aproveita as relações tipo "é um" (is_a) para reconstruir um arquivo em formato GO Flat File utilizável pelo motor de inferência SIFTER. Desta forma as ontologias funcionais utilizadas no pelo motor de inferência SIFTER não ficam limitadas à última versão fornecida em formato Flat File pelo banco Gene Ontology.

\subsubsection{Tipos de evidência}

O Gene Ontology Annotation é um banco de dados que registra anotações das três ontologias que compõem o Gene Ontology para sequências presentes no banco de dados Uniprot Knowledge Base (UniprotKB). Para cada anotação existem, entre outras informações, informações acerca do gene; número de acesso no Uniprot; código GO para a anotação; se a anotação é relativa à função molecular, processo biológico ou componente celular; e o código de evidência. Os códigos de evidência do Gene Ontology fornecem informações acerca da metodologia utilizada para a obtenção da anotação. O motor de inferência Sifter se aproveita do código de evidência para fornecer um valor a priori para cada código, conforme observado na tabela 1. Neste caso o valor da priori para cada tipo de evidência pode ser interpretado como o grau de confiança em cada tipo de evidência. Na versão 120 do banco de dados GOA as anotações funcionais estão distribuídas segundo o quadro I.

Como já foi apontado no item 3.2.1.2, o Gene Ontology adicionou os códigos ISA, ISO e ISM em 2008; e os códigos IBA, IBD, IKR e IRD em 2011. Estes códigos ainda não são suportados pelo motor de inferência Sifter, apesar de já representarem cerca de 5,6\% das anotações não-IEA. Como é importante que o Sifter tenha acesso a todos os códigos de evidência de interesse do pesquisador elaboramos estratégias para utilizar corretamente as não-anotações (IKR e IRD), e os novos códigos de anotações (ISA, ISO, ISM, IBD e IBA).

No caso das funções moleculares as não-anotações representam evidências de que, apesar de alguns métodos apontarem para certa função, a sequência em questão não possui a função apontada. Para aproveitar esse tipo de evidência nós realizamos 
filtragens das não-anotações e seus descendentes segundo a ontologia GO, gerando um arquivo somente com as anotações positivas.

Quadro I - Número de anotações funcionais para cada tipo de evidência no banco de dados GOA.

\begin{tabular}{|c|c|}
\hline $\begin{array}{c}\text { Código de } \\
\text { Evidência }\end{array}$ & $\begin{array}{c}\text { Número de anotações } \\
\text { funcionais }\end{array}$ \\
\hline IEA & 73382817 \\
\hline IPI & 96757 \\
\hline ND & 69154 \\
\hline IDA & 63088 \\
\hline ISS & 45217 \\
\hline TAS & 12009 \\
\hline IBA & 10876 \\
\hline IMP & 9586 \\
\hline NAS & 5559 \\
\hline ISO & 3004 \\
\hline IGI & 2764 \\
\hline ISA & 2705 \\
\hline ISM & 1284 \\
\hline IC & 776 \\
\hline EXP & 239 \\
\hline RCA & 146 \\
\hline IGC & 146 \\
\hline IKR & 52 \\
\hline IRD & 38 \\
\hline IBD & 0 \\
\hline IEP & 0 \\
\hline NR & 0 \\
\hline Total & 73706217 \\
\hline & \\
\hline & \\
\hline
\end{tabular}

Para permitir o acesso do motor de inferência Sifter aos novos códigos de anotação nós optamos por substituir os códigos novos por códigos com probabilidade a priori coerente com a confiança esperada. Essa alteração ocorre durante a fase de preparação do arquivo ".pli", que possui as anotações a serem propagadas pelo motor de inferência. Os códigos ISA, ISO, ISM, IBD e IBA são substituídos por ISS (Inferred by sequence or structural similarity) que corresponde à probabilidade inicial de 0,4. 
No item 3.2 também foi levantado que existe uma atribuição incorreta das probabilidades à priori para os códigos de evidência IGI e IGC. Utilizando a mesma estratégia anterior, o código IGI é substituído pelo código IMP (Inferred by mutant phenotype), e o código IGC é substituído pelo código ISS, ambos de probabilidade a priori idêntica às originais.

Com estas alterações a nova implementação está preparada para aproveitar as anotações associadas a todos os códigos de evidência atuais e já possui estrutura para facilmente incorporar outros códigos de evidência que porventura sejam desenvolvidas no futuro.

\subsubsection{Reconstrução de Árvores de Genes e Árvores de Espécies}

Para gerar uma árvore de genes reconciliada são necessárias a árvore de genes, com identificação taxonômica para cada gene; e uma árvore de espécies, contendo no mínimo a estrutura taxonômica com identificação de cada uma das espécies da árvore de genes. Em seguida é realizado o processo de reconciliação que identifica os pontos na árvore de genes onde evolutivamente ocorreram eventos de duplicação ou especiação genética. A seguir vamos apontar nossa estratégia para gerar as arvores de genes reconciliadas.

O primeiro passo é o mapeamento dos genes a suas espécies correspondentes. Apesar de conter sequências do banco de dados não-redundante (Genbank - NCBI) e amostras de metagenoma, os genes do banco de dados PFAM têm origem nos bancos de dados UniprotKB. O UniprotKB possui em seus arquivos o mapeamento dos seus genes aos números de acesso (acession numbers) para as espécies correspondentes segundo o banco de dados NCBI Taxonomy, facilitando assim o mapeamento. Existe um descompasso entre os lançamentos de novas versões dos bancos UniprotKB, NCBI Taxonomy e o PFAM. O UniprotKB é atualizado quinzenalmente, o NCBI Taxonomy é atualizado diariamente e novas versões do banco de dados PFAM são liberadas em intervalos de vários meses.

Devido a este descompasso optamos por utilizar os arquivos do Uniprot utilizados na elaboração do banco de dados PFam, disponíveis no repositório FTP do PFam. Utilizar a versão correspondente do Uniprot garante que todos os genes do 
PFam possuam um termo correspondente no Uniprot, permitindo o mapeamento de suas espécies de acordo com o NCBI Taxonomy. Entretanto, como os termos do NCBI Taxonomy (NCBITaxID) podem ser deletados ou fusionados, não garante que a identificação desta espécie é válida.

Para solucionar a questão dos termos atualizados do NCBI Taxonomy nós recuperamos do repositório FTP do NCBI Taxonomy (ftp://ftp.ncbi.nih.gov/pub/taxonomy/) a lista de espécies deletadas e de termos fusionados. Durante a fase de preparação dos bancos de dados é gerada uma tabela de associação do gene à sua espécie. Durante a elaboração desta tabela os NCBITaxID deletados são marcados, os NCBITaxID fusionados são atualizados e os termos restantes que não foram encontrados no NCBI Taxonomy são tratados como termos deletados. Na fase de preparação dos alinhamentos múltiplos os genes com NCBITaxID marcados são removidos. Ao fim deste processo teremos alinhamentos contendo somente genes com NCBITaxID válidos.

O passo seguinte neste processo é a associação dos genes às suas espécies na árvore de genes. Isso ocorre no passo de conversão da árvore em formato Nexus para o formato New Hampshire eXtended e utiliza mapeamento dos genes ao NCBITaxID correspondente.

A partir do mapeamento de genes a suas espécies podemos recuperar a lista de espécies presentes em uma dada família de proteínas. Para que a árvore de espécies seja construída precisamos então recuperar as informações de todos nós ancestrais que possuam ligação com as espécies da lista. Para isto recuperamos as informações do NCBI Taxonomy (ftp://ftp.ebi.ac.uk/pub/databases/taxonomy/taxonomy.dat), que possui para cada nó a identificação de seu nó parental. Com estas informações reconstruímos a árvore de genes, gerando um arquivo no formato Nexus. Ex:

(9913, (10090, (9606, 9593)));

Esta árvore de espécies é equivalente a:

(COW, (MOUSE, (HUMAN, GORILLA))) ; 
Para este processo utilizamos o pacote Dendropy (Sukumaran \& Holder, 2010; http://pythonhosted.org/DendroPy/), que possui várias funções para manipulação de árvores filogenéticas.

Com a árvore de genes e da árvore de espécies construídas é possível realizar a reconciliação. Ela consiste em determinar que ramos em uma árvore de genes derivaram a partir de eventos de duplicação e que ramos derivaram a partir de eventos de especiação. Este processo no workflow SIFTER original era realizado pela ferramenta SDI, parte do pacote Forester (Zmack \& Eddy, 2001), uma ferramenta simples para realizar tal procedimento, mas incapaz de lidar com árvores de genes e espécies que possuam politomias, ou seja, não sejam completamente binárias. Essa característica nos levou à ferramenta Notung (Vernot et al., 2008). Notung permite a automatização por linha de comando, possui interface gráfica para uma análise mais criteriosa, e é a única ferramenta encontrada capaz de gerar a árvore reconciliada se pelo menos uma das árvores for completamente binária.

Para que esta ferramenta funcionasse corretamente e automaticamente para todas as famílias de proteínas, precisamos garantir que pelo menos uma das árvores de entrada é binária. Como a árvore de genes possui informações de distâncias entre os nós, é mais complexa a adaptação para uma árvore binária em relação a uma árvore de espécies, que possui somente os nomes dos nós. Com a ajuda do pacote Dendropy resolvemos as politomias existentes, substituindo o nó da politomia por estrutura binária com nós fictícios, como representado pela figura 10. Ao fim desta fase teremos uma árvore reconciliada de genes em formato $\mathrm{NHX}$, o formato de entrada aceito pelo motor de inferência SIFTER.

No material suplementar de Engelhardt et al. (2011) é sugerido que as árvores reconciliadas apresentam falsos eventos de duplicação em várias famílias, comprometendo o sinal com ruído. Baseados neste discurso buscamos compreender o motivo dos falsos eventos de duplicação e uma solução para que a duplicação e especiação sejam melhor aproveitadas. Como descrito no item 2.1, os métodos ótimos para a detecção de ortólogos é distinto entre os eucariotos e procariotos. O modelo evolutivo predominante em eucariotos é a reprodução sexuada, enquanto para os procariotos o maior motor evolutivo são as transferências laterais. 


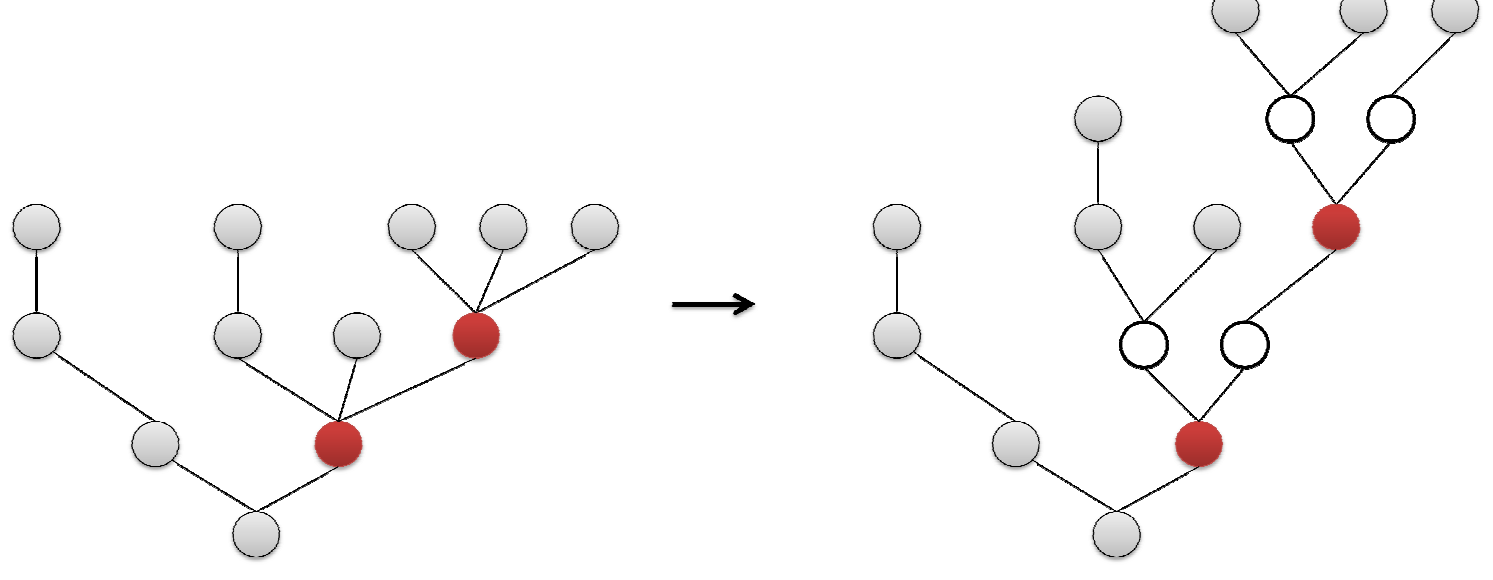

Figura 10 - llustração de como lidamos com politomias em árvores de espécies. Cinza - Nós estritamente binários. Vermelho - Politomia. Branco - Nós falsos introduzidos para adaptar uma politomia a uma estrutura binária, processo também conhecido como resolução de politomia.

Para tratar eficientemente tanto os procariotos quanto os eucariotos realizamos alguns testes com os genomas/proteomas dos principais grandes grupos taxonômicos e chegamos à conclusão que a reconciliação deve ser utilizada somente onde ela é mais bem aproveitada. As anotações nos grupos Metazoa e Viridiplantae são muito beneficiadas pela reconciliação. Para o restante dos eucariotos não conseguimos encontrar um conjunto de parâmetros genérico que otimize a qualidade de suas anotações.

Em relação ao processo de reconciliação, para as eubactérias e arqueobactérias as árvores não devem ser reconciliadas para favorecer o modelo evolutivo baseado em transferências laterais. No entanto, o processo de reconciliação não foi suficiente para a obtenção de anotações de qualidade para estes grupos. O número de anotações para os eucariotos é muito superior ao dos procariotos, o que gera um viés amostral e uma redução da qualidade das anotações dos procariotos. Contornamos esta questão incorporando um sistema de filtragem de anotações por grupo taxonômico, permitindo que sejam retiradas as anotações de certos grupos, como os eucariotos. Retirando-se as anotações de eucariotos da análise a metodologia Sifter obtém bons resultados na anotação dos organismos procariotos. 


\subsection{Design Centrado no Usuário}

\subsubsection{Tipo de dados de entrada}

Como foi apresentado no item 3.2.2.1, o tipo de dado de entrada utilizado pelo workflow Sifter original não é facilmente associado à sequência de interesse do pesquisador, o que gera inconsistências na anotação e dificulta a análise dos dados. Baseado nisso elaboramos estratégias para permitir o uso de sequências de aminoácidos e sequências de nucleotídeos como dados de entrada.

\subsubsection{Aminoácidos}

Como já descrito no item 2.1, as sequências podem ser analisada em diferentes níveis: motivos, domínios, genes/proteínas completas ou suas estruturas secundária e terciária.

Engelhardt propõe duas metodologias para a associação da sequência de aminoácidos com a família de proteínas. A primeira (metodologia utilizada na implementação de sifter0.3) consiste na busca por similaridade com a ajuda de "hmmsearch", uma das ferramentas do software HMMER, incorporar a sequência completa ao alinhamento e prosseguir com a anotação. A segunda (não implementada) consiste numa busca por similaridade da sequência de interesse com as sequências do PFam, realizar a anotação da família de proteínas e realizar a transferência da anotação da sequência de maior similaridade para a sequência de interesse.

Ambas as estratégias obtém resultados razoáveis caso a sequência possua somente um domínio protéico a ser anotado, mas não é confiável no caso de proteínas multidomínio. Segundo Ekman et al. (2005), estima-se que 65\% das proteínas de eucariotos e $40 \%$ de procariotos possuem mais de um domínio protéico. Sendo assim, buscamos estratégias capazes de lidar eficientemente com sequências multidomínio.

Outra ferramenta de anotação funcional a se destacar no CAFA Experiment, chamada de "Team Orengo" (Rentzsch \& Orengo, 2013) se aproveita da anotação parcial da proteína para aumentar a qualidade da anotação. Segundo Rentzsch \& Orengo (2013) uma das principais características que permitiram esta qualidade de anotação funcional é a anotação dos domínios protéicos individualmente, pois existe uma correlação maior de homologia entre sequências de domínios que entre 
sequências completas de proteínas. Sendo esta uma estratégia bem sucedida, vamos utilizá-la para a anotação das sequências de aminoácidos por meio da metodologia Sifter.

O banco de dados PFAM, origem dos nossos alinhamentos múltiplos, contém alinhamentos de domínios e motivos de proteínas, regiões importantes para a determinação da função de uma proteína. Para o reconhecimento dos domínios protéicos a partir de sequências de aminoácidos, optamos pelo uso da variante local da ferramenta PFAM Search, a ferramenta "pfam_scan.pl", fornecida pelo próprio PFAM (http://pfam.sanger.ac.uk). Esta ferramenta depende do software HMMER v3.0, disponível em http://hmmer.janelia.org/; e de outros arquivos do próprio banco PFAM, que contém os perfis de reconhecimento das famílias de proteínas. Ao final do processo recuperamos, para cada sequência de aminoácidos, os trechos em que foram reconhecidas famílias de proteínas, a quais famílias de proteína os segmentos estão associados e um e-value indicando o nível de similaridade entre o segmento e o perfil da família. Desta forma somente os trechos de interesse serão utilizados, podendo variar de zero a muitas regiões em uma mesma sequência de aminoácidos e associadas a distintas famílias de proteínas. Nesta abordagem cada domínio identificado será anotado independentemente dos vizinhos, permitindo anotações funcionais distintas em uma mesma proteína. O reconhecimento dos domínios de proteína depende, neste caso, da cobertura de sequências do banco de dados PFAM, que é ampliada a cada versão do banco de dados. Caso não seja reconhecido nenhum domínio conhecido em uma proteína não será possível anotá-la por meio da metodologia SIFTER.

\subsubsection{Nucleotídeos}

Partindo de nucleotídeos esta busca possui maiores complicadores, principalmente relativos às origens destas sequências. Estas sequências podem ter origem genômica, origem em pre-mRNAs, mRNAs ou sub-sequências de cDNA, como os ESTs. Além disso, a busca deve ser capaz de lidar com sequências de diversos grupos de organismos diferentes, com padrões distintos de genes. Para tal objetivo começamos estudando as abordagens mais utilizadas para a determinação de sequências codificantes. 
Os identificadores de genes (gene finders, ou alternativamente, anotadores de genes, termo este evitado neste trabalho para evitar ambigüidade, pois se trata de outro tipo de anotação que não a funcional), uma das alternativas mais comuns para esse tipo de problema, se mostraram pouco eficientes para esta abordagem. Gene finders dependem de treinamento de dados para gerar o perfil de reconhecimento de genes ou fase aberta de leitura (ORF), ou são específicos para um grupo de organismos (e.g. GLIMMER, GeneMark, GENSCAN, SNAP, mSplicer, CONTRAST e mGene). Além disso, existem complicadores intrínsecos de cada grande grupo de organismo. Procariotos podem possuir genes sobrepostos na fita sense em outros frames de leitura ou na fita antisense; genes de eucariotos podem sofrer de splicing alternativo, possuindo trechos codificantes em frames distintas; e ambos podem ter domínios múltiplos e distintos em seus genes, apontando para famílias de proteínas distintas.

Os identificadores de fase aberta de leitura (ORF Finders) também possuem revezes. No caso de sequências genômicas é necessário determinar para cada gene em que fase de leitura os genes estão e a localização do começo e fim de cada região codificante. Entretanto os ORF Finders têm dificuldade em lidar com regiões intrônicas (eucariotos), que interrompem a fase codificante e podem mudar a fase de leitura do restante da região codificante; genes sobrepostos (procariotos) em diferentes fases de leitura; e com sub-sequências incompletas da região codificante (e.g. ESTs), que freqüentemente não possui o códon iniciador e/ou terminador.

Para atacar este problema de forma suficientemente universal e eficiente tratamos as sequências de nucleotídeos de forma genérica, baseado no funcionamento da ferramenta blastx (Altschul et al., 1990; Boratyn et al., 2013). As sequências de nucleotídeos são traduzidas segundo sua tabela de tradução (um dos parâmetros de entrada) em suas 6 fases de leitura (reading frames). Estas traduções são então tratadas da mesma forma que as sequências de aminoácidos para a determinação dos domínios protéicos. Como esta abordagem não necessita de determinação exata do início e fim das regiões codificantes e é capaz de lidar com sequências parciais, permite a aplicação a sequências de qualquer grupo de organismo e com qualquer tipo de sequência. Entretanto, por ser uma abordagem genérica e inclusiva esperamos uma taxa relativamente maior de falso-positivos em relação aos 
gene finders e ORF finders. Acreditamos ainda que com esta abordagem podemos colocar em foco regiões que não seriam descobertas de outra forma.

\subsubsection{Incorporação das sequências de entrada aos alinhamentos múltiplos}

Edgar e Batzoglou (2006) consideram que os programas MAFFT (Katoh \& Toh, 2010) e MUSCLE (Edgar (a), 2004; Edgar (b), 2004) são os mais indicados para análises em larga escala, pois escalam bem e possuem opções de execução que reduzem o consumo de memória, um problema comum com alinhamentos com grande número de sequências e com sequências de grande extensão. As grandes famílias de proteína também são um problema enfrentado pela equipe do PFAM (e.g. http://xfam.wordpress.com/2012/02/27/proposed-changes/\#more-710).

À primeira vista o realinhamento das sequências poderia ser feito com qualquer ferramenta, porque o alinhamento original já é bem consolidado e a adição de uma única sequência não deve ser suficiente para perturbar o alinhamento original. Apesar disso o PFAM possui alguns alinhamentos de dimensão muito grande, impossibilitando o uso de softwares menos escaláveis. As duas ferramentas de alinhamento múltiplo possuem alta escalabilidade e são utilizadas em projetos nos quais o alinhamento múltiplo é uma etapa crucial (e.g. PFAM Project).

Após testes com cada uma das ferramentas (testes de uso de memória estão no item 5.2) chegamos à conclusão que MAFFT se adéqua melhor às necessidades desse workflow. Além de ser uma ferramenta que gera alinhamentos de qualidade equivalente às outras duas, MAFFT possui funções que permitem incorporar sequências a um alinhamento pré-estabelecido sem perturbá-lo, o que reduz o custo computacional deste processo e aumenta a qualidade do alinhamento final; e ele se aproveita do paradigma de multiprocessamento, reduzindo o tempo de execução necessário para a conclusão de sua tarefa.

\subsubsection{Estrutura do arquivo de saída}

$\mathrm{O}$ arquivo de saída do motor de inferência Sifter é de difícil interpretação. Para sanar esta deficiência nós elaboramos um módulo que agrega os parâmetros iniciais da execução da nova implementação, as informações sobre os genes não-tratáveis por não possuírem domínios identificados, sobre os genes com domínios em famílias de 
proteína sem anotações para serem propagadas e as anotações obtidas pelo Sifter, organizadas de forma a facilitar a compreensão de forma mais eficiente e mais rápida.

Este módulo gera três arquivos. Todos os três possuem um cabeçalho com as informações dos parâmetros utilizados na execução da anotação em questão, marcados com "\#" para facilitar o tratamento de texto. Um dos arquivos está organizado em formato tsv (tab-separated values - valores separados por tabulações), o que facilita o tratamento de texto para filtragem dos dados de interesse. As colunas estão organizadas da seguinte forma:

$<$ Nome do gene> <frame de leitura> <posição inicial> <posição final> <família de proteína> $<$ probabilidade da anotação > <Código GO > <Nome completo do código GO>

O segundo e o terceiro arquivo possuem 5 blocos de informação. O primeiro é o cabeçalho, com as informações dos parâmetros. O segundo bloco possui a lista de genes que não possuem domínios identificados, genes em que não é possível a anotação pela metodologia Sifter. O terceiro bloco contém os genes em que foi identificado um domínio, mas sua família de proteínas não tem anotações que possam ser propagadas, portanto, também não é possível a anotação pela metodologia Sifter. O quarto bloco é semelhante ao terceiro, e possui famílias de proteínas em que existem anotações que possam ser propagadas, mas que as anotações foram retiradas pela seleção de códigos de evidência ou filtragem taxonômica.

O último bloco de informação é o que difere os dois arquivos restantes. Em ambos os casos são apresentados os genes anotados, mas em um dos arquivos eles estão organizados em relação aos genes de entrada e no outro os genes anotados estão organizados em relação às famílias de proteínas.

$\mathrm{O}$ arquivo organizado por genes apresenta a seguinte estrutura:

[nome do gene]

[fase de leitura (se nucleotídeo)] - [posição inicial]-[posição final] - [código da família de proteínas]

PROB_MAX CÓDIGO_GO DESCRIÇÃO_GO

PROB_MÉD CÓDIGO_GO DESCRIÇÃO_GO

PROB_MIN CÓDIGO_GO DESCRIÇÃO_GO 
O arquivo organizado por famílias de proteínas apresenta a seguinte estrutura:

[código da família de proteínas]

[nome do gene][[fase de leitura(se nucleotídeo)]|[posição inicial]-[posição final]

$\begin{array}{lll}\text { PROB_MAX } & \text { CÓDIGO_GO } & \text { DESCRIÇÃO_GO } \\ \text { PROB_MÉD } & \text { CÓDIGO_GO } & \text { DESCRIÇÃO_GO } \\ \text { PROB_MIN } & \text { CÓDIGO_GO } & \text { DESCRIÇÃO_GO }\end{array}$

Fornecendo estas alternativas acreditamos que as principais informações requisitadas pelos pesquisadores estão cobertas.

\subsubsection{Dificuldade no uso da ferramenta e documentação}

No item 3.2.2.3 foram levantadas as principais dificuldades no uso da metodologia Sifter original. As principais queixas foram a documentação limitada, confusa e desatualizada; a necessidade de alterar parâmetros manualmente dentro do código fonte; e a necessidade de uma compreensão aprofundada da metodologia para que seja possível concluir os todos passos corretamente.

Para sanar a necessidade de alteração dos parâmetros dentro do código fonte foi elaborada uma interface de entrada de parâmetros em linha de comando. Esta interface fornece orientações básicas sobre como os parâmetros devem ser utilizados; indica onde se informar sobre certos itens na documentação ou em materiais online; e fornece ao pesquisador informações acerca do andamento do processo de anotação. Para complementar a interface foi elaborado um módulo completo de checagem da validade e conflitos para todos os parâmetros; se o conteúdo dos arquivos de entrada são bem formados e válidos; presença dos softwares, pacotes e módulos utilizados; e permissões de leitura, escrita e execução de pastas e arquivos, evitando interrupções indesejadas ao longo da execução da anotação.

A documentação foi reformulada e atualmente possui de forma organizada e com orientações mais claras informações sobre os requerimentos do sistema; softwares e versões requeridas; bancos de dados biológicos, com orientações simples sobre a obtenção e preparação dos arquivos; instruções detalhadas passo a passo acerca da instalação e utilização típica dos parâmetros; informações detalhadas sobre a interpretação dos arquivos de saída; e tutorial para teste da metodologia. A 
documentação é atualizada à medida que são incluídos recursos no pacote da nova implementação. A versão mais recente estará disponível no repositório GIT (https://github.com/dcasbioinfo/sifter-t.git) e versões estáveis estarão disponíveis também no repositório institucional (http://labpib.fmrp.usp.br/methods/sifter-t/).

Com estas alterações e a automação aprofundada do processo de anotação pela metodologia Sifter, concluímos que a implementação atual da metodologia está acessível pelo usuário médio estabelecido (cientistas da área biológica com conhecimentos básicos no uso de ferramentas de bioinformática e interessados principalmente na anotação funcional de seu próprio conjunto de genes).

\section{3 - Visão global da nova implementação}

As alterações no workflow se dividiram em duas fases. A fase de preparação de dados e a fase de anotação. A preparação de dados permite que a fase de anotação seja mais eficiente, reduzindo redundâncias e automatizando vários passos que anteriormente eram manuais. A fase de preparação de dados será abordada em mais detalhes no item 5.3.

A fase de anotação está esquematizada na figura 11. Em linhas gerais ela compreende a checagem de parâmetros, representada pela linha pontilhada; a recuperação da lista de famílias de proteínas e seus alinhamentos múltiplos; a filtragem das sequências sem anotação e das anotações de espécies removidas; a geração das árvores de genes; a recuperação das árvores de espécies, se necessário; a recuperação das anotações para cada família de proteínas; a anotação utilizando o motor de inferência Sifter; e a integração de informações de todos os passos nos arquivos "REPORT.txt", "REPORT_alt.txt" e "REPORT.tab". 


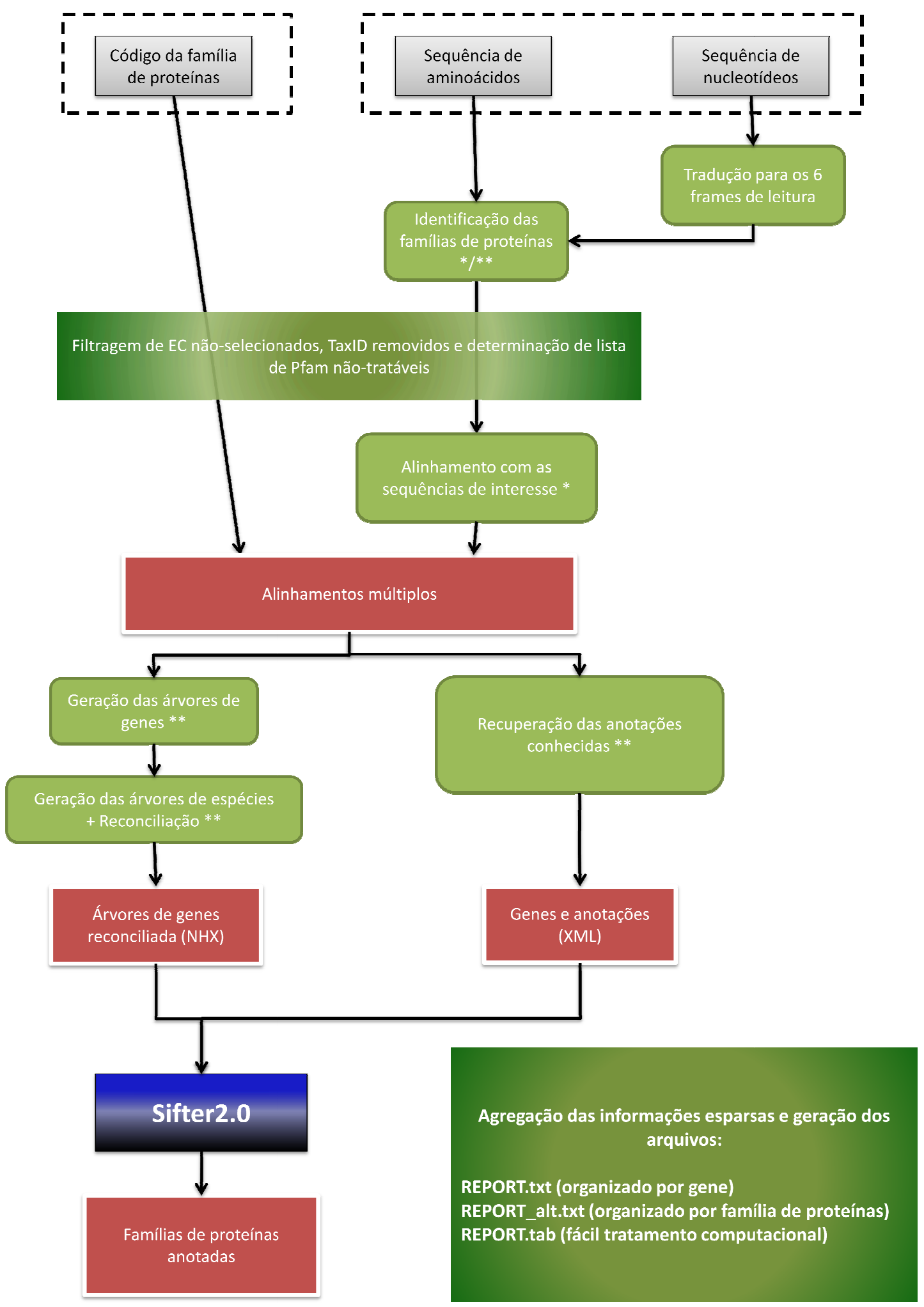

Figura 11 - Workflow SIFTER modificado. Cinza - dados de entrada; Verde - principais módulos de processamento; Vermelho - Arquivos de saída do workflow SIFTER; Azul/preto - Motor de inferência SIFTER; * - passo com multiprocessamento de baixa granularidade; ${ }^{* *}$ - passo com multiprocessamento de alta granularidade. 


\section{CAPÍtULO 5 \\ Metodologia e Resultados - Performance}

No item 3.2.3 foi levantado que a metodologia Sifter possui gargalos de performance, abrangendo o aproveitamento do processamento, consumo de memória e acesso ao disco. Neste capitulo serão apresentadas as estratégias e os resultados obtidos no aperfeiçoamento da escalabilidade da metodologia Sifter.

No item 5.1 serão exploradas as otimizações voltadas ao uso dos núcleos inativos em máquinas multicore, no item 5.2 serão explorados os gargalos de memória e estratégias de filtragem, e no item 5.3 será explorada a metodologia para redução de redundância de processamento.

Para descobrir que trechos do workflow eram passíveis de otimização utilizamos módulos de perfilagem, como o módulo cProfile (http://docs.python.org/library/profile.html), nativo do python, quando o código estava organizado em funções e classes. Como os scripts originais não estavam organizados desta forma utilizamos o módulo "line_profiler" (http://packages.python.org/line profiler/), que fornece informações de tempo de execução gasto linha a linha e quantas vezes cada linha era executada. Para perfilagem de softwares de terceiros e tempo de execução de scripts utilizamos a ferramenta "time", presente em várias distribuições Linux. Ela fornece informações relativas à percentagem de uso do processador, tempo consumido na execução do software e limite superior de uso de memória.

Os testes em que foi verificada a utilização de memória foram realizados em um servidor de processamento equipado com dois processadores Intel ${ }^{\circledR} \mathrm{Xeon}^{\circledR}$ Six Core X5660 e 48GB de memória RAM. Os testes relativos ao uso otimizado dos núcleos foram realizados em desktop com um processador Intel ${ }^{\circledR}$ Core 2 Quad Q6600 com 4GB de memória RAM. 


\subsection{Perfilagem e otimizações de performance}

Segundo a lei de Moore, o número de transistores dos chips dobrariam, pelo mesmo custo, a cada período de 18 meses. Após a indústria de chips encontrar um limite em relação à velocidade, em Hertz, dos processadores devido ao problema do aquecimento, a estratégia atual para que o poder dos processadores siga a Lei de Moore é o aumento de núcleos.

Objetivando a melhora do desempenho do pipeline da metodologia SIFTER pelo aproveitamento mais eficiente dos núcleos do processador, foram estudadas abordagens de uso de múltiplos threads e processos, por meio de módulos nativos de Python v2.7. Foram testadas abordagens com o módulo "threading" e, após alguns insucessos, foi testado o módulo "multiprocessing". O uso de threading é uma forma de um processo dividir a si mesmo em várias tarefas, que podem ser processadas concorrentemente. Esta é uma forma mais leve de aproveitar múltiplos núcleos em uma mesma máquina, pois há o compartilhamento de memória e não há a necessidade de duplicar todo o processo. Esta abordagem não foi bem sucedida, devido a peculiaridades da linguagem Python.

O interpretador de Python possui uma característica para proteger, no caso de uso de threads, as variáveis em memória. Esta é uma trava global, chamada de Global Interpreter Lock (GIL). Ela impede o acesso/gravação simultâneo(a) de variáveis por threads diferentes, impedindo vários erros de execução. Entretanto, da forma que foi implementada ela impede o paralelismo verdadeiro em máquinas multicore.

Os processos, por outro lado, são módulos separados com recursos nãocompartilhados e isso implica em maiores demandas de memória e processador, acompanhados de maior segurança na execução paralelizada. Em Python, a melhor solução apresentada para aproveitamento otimizado dos núcleos é o módulo "multiprocessing". Esta é uma alternativa recente ao problema no gerenciamento dos threads, e aparentemente foi implementada para suprir a demanda por aproveitamento dos núcleos. Na documentação do Python (http://docs.python.org/library/multiprocessing.html), é referenciada como "Processbased 'threading' interface". 
Segundo a Lei de Amdahl, uma teoria fundamental da computação paralela, o ganho de desempenho que pode ser obtido melhorando uma determinada parte do sistema é limitado pela fração de tempo que esta parte é utilizada pelo sistema durante sua operação (Pacheco, 1997). Tendo em vista o ganho mais expressivo de desempenho dos scripts, aplicamos inicialmente a paralelização em trechos do pipeline que consumiam mais tempo de execução. Segundo Bernstein (1966), fragmentos do programa podem ser executados em paralelo quando são independentes.

Conforme uma análise superficial utilizando a ferramenta "line_profiler", os trechos do workflow SIFTER que eram independentes e apresentariam maiores benefícios se paralelizados seriam a montagem do arquivo ".pli" no script "pfam2sifter.py", e a geração de árvore a partir do alinhamento múltiplo, no script "pull_alignments.py". Seus testes foram realizados com o dataset "Hundred Families Dataset", também utilizado por Engelhardt e disponível em http://sifter.berkeley.edu/.

Para a geração de árvore a partir do alinhamento múltiplo (pull_alignments.py) foram testadas duas abordagens. A ferramenta "FastTree" possui uma implementação que nativamente aproveita melhor os núcleos, o "FastTreeMP", mas que segundo a documentação fornece árvores ligeiramente diferentes da "FastTree". Foram testadas a paralelização nativa (FastTreeMP) e a paralelização de alta granularidade da ferramenta "FastTree" por meio do módulo python "multiprocessing". Para este teste o uso de memória não foi limitante, portanto não foi avaliado em detalhes. A paralelização do FastTree por meio do módulo "multiprocessing" foi a implementação com melhor desempenho em todos os casos, alcançando um ganho de 63,8\% (Figura 12).

A recuperação da anotação dos genes conhecidos (pfam2sifter.py) permitiu, além da paralelização por meio de módulos python, outras formas de aperfeiçoamento. Em cada execução a fase de recuperação das anotações do arquivo "gene_ontology.goa_uniprot" vasculhava o arquivo inteiro, gerando sobrecarga no acesso ao disco. Além disso, o trecho de código que realizava o vasculhamento utilizava estruturas de dados e testes ineficientes para uma tarefa deste porte. Este 
script também não apresentou uso de memória crítico, portanto não foi avaliado em detalhes.

Para reduzir o acesso ao disco foi gerado um arquivo com as anotações dos genes do "gene_ontology.goa_uniprot" presentes no PFam e somente com os campos de interesse para a metodologia Sifter. Este arquivo possui cerca de $5 \%$ da dimensão do arquivo original, com a mesma funcionalidade. Na nova implementação a geração deste arquivo é realizada na etapa de preparação de dados.

Em relação ao aproveitamento das estruturas de dados mais eficientes, a documentação online de python fornece algumas orientações simplificadas para otimizações deste tipo (http://wiki.python.org/moin/PythonSpeed/PerformanceTips; http://wiki.python.org/moin/TimeComplexity). Um bom exemplo seria a diferença de desempenho entre a lista (list) e o conjunto (set). Ao testar a presença de um valor $\mathrm{x}$ em uma lista de comprimento $n$ temos como complexidade média $O(n)$. 0 mesmo processo se for testado em um conjunto tem complexidade média $\mathrm{O}(1)$. Tendo conhecimento destes recursos, onde foi possível foram aplicadas otimizações relativas ao uso de estruturas de dados mais eficientes para menor utilização de memória e processamento.

O ganho de desempenho médio, em uma máquina de 4 núcleos, superou nossas expectativas, alcançando 87 vezes de redução de tempo de execução (26seg para 100 famílias). O resultado do benchmark deste script está apresentado na figura 13.

Demonstrada a eficiência dos métodos de paralelização dos trechos independentes dos scripts e utilização de estruturas de dados mais eficientes, esta abordagem foi aplicada aos outros scripts. Neste caso obtivemos bons resultados, contudo menos expressivos (dados não apresentados). 


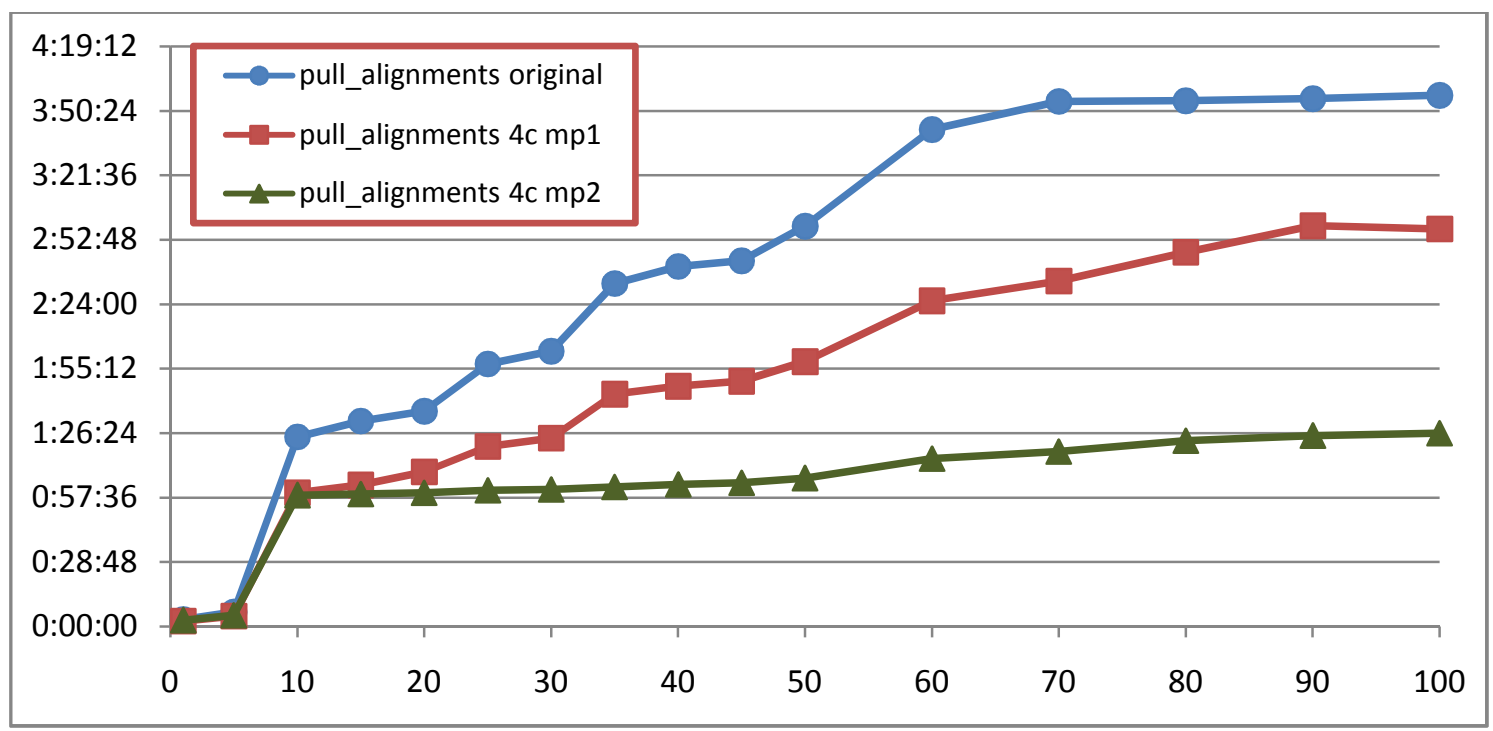

Figura 12 - Linhas de tendência representando os tempos de execução em máquina quadcore para o script "pull_alignments.py" em relação ao número de famílias de proteínas de entrada. Azul - script original; Vermelho - substituição de FastTree por FastTreeMP (mp1); Verde - Implementação paralelizada do FastTree (mp2).

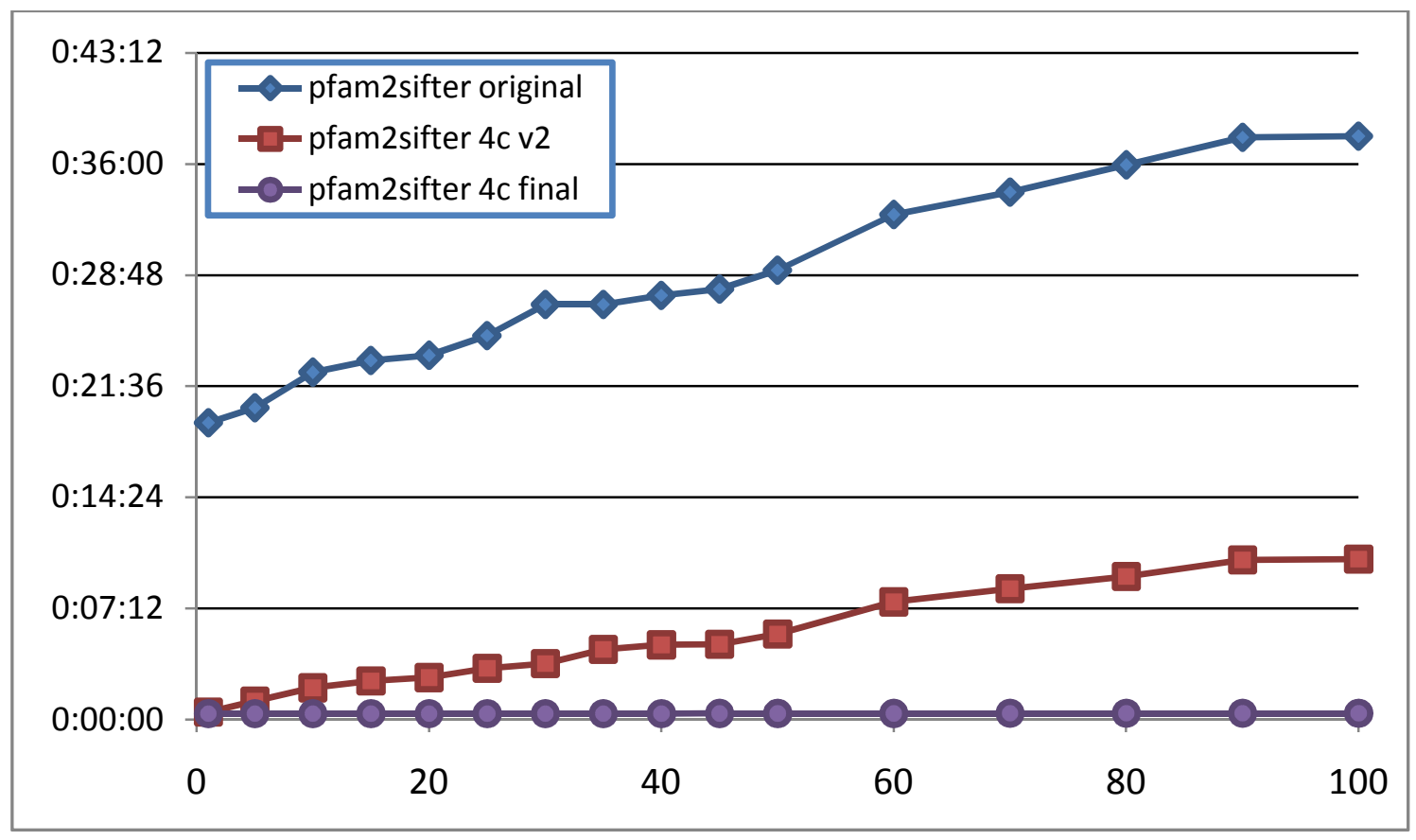

Figura 13 - Linhas de tendência representando os tempos de execução para o script "pfam2sifter.py" original e novas implementações em relação ao número de famílias de proteínas de entrada. Azul - Curva de tempo para o script original; Vermelho - Implementações de multithreading e acesso a disco; Púrpura - Implementações de multithreading, acesso a disco e substituição de estruturas de dados por soluções equivalentes de maior desempenho. 


\subsection{Gargalos de Memória e Sistemas de filtragem}

Todos os testes anteriores foram aplicados no conjunto de dados "hundred families" (http://sifter.berkeley.edu/). Para testar a escalabilidade da metodologia foi necessário aplicá-la a todas as famílias de proteínas, em especial as maiores famílias de proteínas do PFam.

\subsubsection{Alinhamento múltiplo}

No item 4.2.1.3 foi levantado que as ferramentas MUSCLE e MAFFT são as melhores candidatas para lidar com o "realinhamento". Apesar disso, mesmo com o uso destas ferramentas nosso grupo enfrentou problemas de esgotamento de memória. Com o intuito de verificar os limites da utilização desta abordagem, foram realizados alinhamentos teste da inclusão de uma das sequências do alinhamento no próprio alinhamento. Este procedimento foi repetido para todas as famílias da versão 25 do banco de dados PFAM, e o uso máximo de memória foi averiguado com a ferramenta "time". A partir da assintótica de complexidade espacial das ferramentas fizemos a curva de referência de consumo de memória para todas as famílias. A complexidade espacial de MUSCLE segue $O\left(N^{2}+L^{2}\right)$, no qual $N$ é o número de sequências no alinhamento e L é o comprimento deste alinhamento (Edgar (a), 2004), sendo a mesma complexidade espacial da última versão de MAFFT. Para a ferramenta MUSCLE, apesar da proporção não ser exatamente a mesma à medida que percorremos as famílias em direção às de menor consumo de memória, para as 300 maiores famílias a proporção se manteve relativamente estável na taxa de 127:1 (BigO:memória). Para a ferramenta MAFFT esta proporção foi mais instável, manteve a mesma taxa média que a ferramenta MUSCLE, mas a ferramenta foi capaz de lidar com consumos maiores de memória. Com estes valores pudemos estimar o consumo máximo de memória para as maiores famílias de proteínas e estimar quais são os limites superiores de memória (Quadro II).

Dentre as duas ferramentas testadas, selecionamos a ferramenta MAFFT para a realização dos alinhamentos no workflow SIFTER. Apesar de MUSCLE gerar alinhamentos levemente superiores em qualidade, MAFFT em sua última versão é multiprocessada e possui recursos de incorporação de sequência ao alinhamento, 
reduzindo significativamente o tempo de execução. Esta característica é essencial para a aplicação da metodologia em larga escala.

Quadro II - Maiores famílias de proteína e consumo de memória para ferramentas MAFFT e MUSCLE. Amostra das maiores famílias de proteínas e seu consumo de memória observado e estimado segundo os valores de comprimento das sequências (L) e número de sequências (N). Seguindo a ordem de tamanhos, para a ferramenta MUSCLE de PF00005 a PF00528 não foi possível realizar o alinhamento por falha de segmentação (memória insuficiente). A ferramenta MAFFT não inicia o alinhamento se o consumo de memória previsto supera a memória livre, não realizando o alinhamento de PF00005 a PF00096.

\begin{tabular}{|c|c|c|c|c|c|c|c|c|c|c|c|}
\hline \multicolumn{4}{|c|}{ 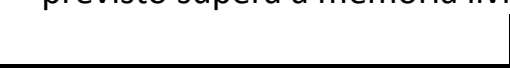 } & \multirow{2}{*}{$\begin{array}{l}\text { MUSCLE } \\
\text { Uso de } \\
\text { memória } \\
\text { (MB) }\end{array}$} & \multicolumn{3}{|c|}{ 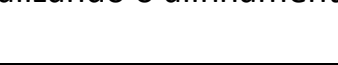 } & \multirow{2}{*}{$\begin{array}{l}\text { MAFFT } \\
\text { Uso de } \\
\text { memória } \\
\text { (MB) } \\
\end{array}$} & & & \\
\hline PFAM & $\mathbf{N}$ & $\mathbf{L}$ & $\mathrm{N}^{2}+\mathrm{L}^{2}$ & & Razão & $\begin{array}{l}\text { Uso } \\
\text { estimado }\end{array}$ & Erro & & Razão & $\begin{array}{l}\text { Uso } \\
\text { estimado }\end{array}$ & Erro \\
\hline PF00005 & 163029 & 1599 & 26841696612 & 8411 & - & 206408 & - & 22 & - & 227958 & - \\
\hline PF00078 & 126258 & 1500 & 16132721064 & 24952 & - & 124062 & - & 22 & - & 137019 & - \\
\hline PF00115 & 118265 & 1196 & 14129486777 & 9688 & - & 108658 & - & 22 & - & 120008 & - \\
\hline PF00516 & 105452 & 1297 & 11258579054 & 20541 & - & 86582 & - & 22 & - & 95628 & - \\
\hline PF00400 & 101999 & 321 & 10436641042 & 14301 & - & 80262 & - & 22 & - & 88648 & - \\
\hline PF00077 & 93675 & 356 & 8808481017 & 1848 & - & 67742 & - & 22 & - & 74822 & - \\
\hline PF00096 & 88330 & 81 & 7809350272 & 26959 & - & 60060 & - & 22 & - & 66338 & - \\
\hline PF00072 & 75322 & 777 & 5732533384 & 11119 & - & 44090 & - & 44810 & 124,96 & 48702 & $8,69 \%$ \\
\hline PF07690 & 69503 & 2814 & 5034169861 & 5692 & - & 38720 & - & 41035 & 119,83 & 42771 & $4,23 \%$ \\
\hline PF02518 & 70410 & 940 & 5024638040 & 5697 & - & 38647 & - & 39404 & 124,56 & 42691 & $8,34 \%$ \\
\hline PF00033 & 70463 & 645 & 5010899674 & 5604 & - & 38541 & - & 39071 & 125,28 & 42574 & $8,97 \%$ \\
\hline PF00528 & 70027 & 1206 & 4989688933 & 5420 & - & 38378 & - & 39316 & 123,97 & 42394 & $7,83 \%$ \\
\hline PF00361 & 60333 & 1126 & 3709274849 & 28399 & 127,60 & 28532 & $0,47 \%$ & 29295 & 123,69 & 31521 & $7,60 \%$ \\
\hline PF00069 & 56691 & 2430 & 3357535941 & 25671 & 127,78 & 25827 & $0,61 \%$ & 27385 & 119,77 & 28534 & $4,19 \%$ \\
\hline PF00032 & 51006 & 307 & 2617365434 & 20085 & 127,32 & 20136 & $0,25 \%$ & 20470 & 124,93 & 22248 & $8,69 \%$ \\
\hline PF00106 & 50144 & 1373 & 2585154950 & 19804 & 127,54 & 19888 & $0,43 \%$ & 20742 & 121,77 & 21975 & $5,94 \%$ \\
\hline PF06817 & 50191 & 109 & 2524619290 & 19353 & 127,46 & 19423 & $0,36 \%$ & 21523 & 114,61 & 21461 & $-0,29 \%$ \\
\hline PF00583 & 46279 & 503 & 2165277690 & 16600 & 127,45 & 16660 & $0,36 \%$ & 17003 & 124,44 & 18409 & $8,27 \%$ \\
\hline PF00271 & 42435 & 694 & 1830661445 & 14050 & 127,33 & 14087 & $0,26 \%$ & 14464 & 123,69 & 15568 & $7,63 \%$ \\
\hline PF00126 & 41545 & 193 & 1734042652 & 13313 & 127,30 & 13344 & $0,23 \%$ & 13489 & 125,63 & 14747 & $9,33 \%$ \\
\hline PF03466 & 40890 & 1177 & 1721506136 & 13214 & 127,33 & 13247 & $0,26 \%$ & 13871 & 121,29 & 14641 & $5,55 \%$ \\
\hline PF00512 & 40899 & 322 & 1686001685 & 12956 & 127,18 & 12974 & $0,14 \%$ & 13169 & 125,12 & 14339 & $8,89 \%$ \\
\hline PF00098 & 39496 & 37 & 1561396774 & 11996 & 127,22 & 12016 & $0,17 \%$ & 14797 & 103,13 & 13281 & $-10,24 \%$ \\
\hline PF00009 & 37224 & 1811 & 1456320372 & 11168 & 127,46 & 11208 & $0,36 \%$ & 12022 & 118,40 & 12389 & $3,05 \%$ \\
\hline PF00571 & 36014 & 395 & 1311390146 & 10085 & 127,11 & 10094 & $0,08 \%$ & 10337 & 124,02 & 11158 & $7,95 \%$ \\
\hline PF00132 & 36123 & 114 & 1309002261 & 10053 & 127,28 & 10075 & $0,22 \%$ & 10202 & 125,43 & 11138 & $9,18 \%$ \\
\hline PF00501 & 33063 & 2831 & 1194780714 & 9129 & 127,95 & 9197 & $0,75 \%$ & 10290 & 113,51 & 10168 & $-1,19 \%$ \\
\hline PF00016 & 34183 & 541 & 1187263714 & 9131 & 127,12 & 9139 & $0,09 \%$ & 9758 & 118,95 & 10104 & $3,55 \%$ \\
\hline PF00892 & 33687 & 667 & 1157728754 & 8904 & 127,12 & 8912 & $0,09 \%$ & 9252 & 122,33 & 9853 & $6,50 \%$ \\
\hline PF01560 & 32118 & 548 & 1049467440 & 8074 & 127,10 & 8080 & $0,07 \%$ & 8348 & 122,91 & 8934 & $7,02 \%$ \\
\hline
\end{tabular}

\subsubsection{Filtragem de Sequências}

Mesmo apresentando bom desempenho, estas ferramentas não foram capazes

de tratar todas as famílias de proteínas. Pensamos então em uma estratégia para que

este consumo de memória seja reduzido sem prejuízo para a anotação. Chegamos 
então à conclusão que a melhor estratégia seria a retirada das sequências sem anotação de cada uma das famílias de proteína. Com a simples retirada de sequências o alinhamento não será prejudicado, assim como as distâncias entre as sequências anotadas e a serem anotadas. O Quadro III apresenta os resultados para as maiores famílias de proteínas. É possível observar que, apesar desta abordagem possuir eficiência variável (redução de 0,49\% no consumo de memória para PF00077; 99,54\% de redução para PF01560), ela torna algumas das maiores famílias de proteína tratáveis pela metodologia SIFTER (e.g. PF00400, PF00516).

Quadro III - Redução de consumo de memória por remoção de proteínas não anotadas. Amostra das maiores famílias de proteínas, seu número de sequências $(\mathrm{N})$ total, número de sequências anotadas, a diferença entre o número total e o número de sequências anotadas, o uso de memória estimado para cada $\mathrm{N}$ e a diferença entre os consumos de memória estimados para a ferramenta MAFFT.

\begin{tabular}{|c|c|c|c|c|c|c|}
\hline PFAM & $\mathrm{N}$ total & $\mathrm{N}$ anotadas & Redução & $\begin{array}{c}\text { Uso de memória } \\
\text { estimado (MB) (N } \\
\text { total) }\end{array}$ & $\begin{array}{l}\text { Uso de memória } \\
\text { estimado (MB) } \\
\text { (N anotados) }\end{array}$ & $\begin{array}{c}\text { Redução no } \\
\text { consumo de } \\
\text { memória }\end{array}$ \\
\hline PF00005 & 163029 & 150604 & $7,62 \%$ & 206408 & 176290 & $14,59 \%$ \\
\hline PF00078 & 126258 & 125595 & $0,53 \%$ & 124062 & 122770 & $1,04 \%$ \\
\hline PF00115 & 118265 & 117562 & $0,59 \%$ & 108658 & 107377 & $1,18 \%$ \\
\hline PF00516 & 105452 & 13988 & $86,74 \%$ & 86582 & 1667 & $98,07 \%$ \\
\hline PF00400 & 101999 & 18251 & $82,11 \%$ & 80262 & 2617 & $96,74 \%$ \\
\hline PF00077 & 93675 & 93446 & $0,24 \%$ & 67742 & 67412 & $0,49 \%$ \\
\hline PF00096 & 88330 & 75490 & $14,54 \%$ & 60060 & 43877 & $26,94 \%$ \\
\hline PF00072 & 75322 & 70230 & $6,76 \%$ & 44090 & 38360 & $12,99 \%$ \\
\hline PF07690 & 69503 & 17708 & $74,52 \%$ & 38720 & 2865 & $92,60 \%$ \\
\hline PF02518 & 70410 & 65056 & $7,60 \%$ & 38647 & 33031 & $14,53 \%$ \\
\hline PF00033 & 70463 & 66627 & $5,44 \%$ & 38541 & 34478 & $10,54 \%$ \\
\hline PF00528 & 70027 & 66137 & $5,56 \%$ & 38378 & 34269 & $10,71 \%$ \\
\hline PF00361 & 60333 & 58573 & $2,92 \%$ & 28532 & 26908 & $5,69 \%$ \\
\hline PF00069 & 56691 & 51988 & $8,30 \%$ & 25827 & 21809 & $15,56 \%$ \\
\hline PF00032 & 51006 & 49078 & $3,78 \%$ & 20136 & 18648 & $7,39 \%$ \\
\hline PF00106 & 50144 & 46932 & $6,41 \%$ & 19888 & 17457 & $12,23 \%$ \\
\hline PF06817 & 50191 & 50094 & $0,19 \%$ & 19423 & 19348 & $0,39 \%$ \\
\hline PF00583 & 46279 & 43532 & $5,94 \%$ & 16660 & 14752 & $11,45 \%$ \\
\hline PF00271 & 42435 & 38286 & $9,78 \%$ & 14087 & 11489 & $18,44 \%$ \\
\hline PF00126 & 41545 & 39544 & $4,82 \%$ & 13344 & 12093 & $9,37 \%$ \\
\hline PF03466 & 40890 & 37968 & $7,15 \%$ & 13247 & 11449 & $13,57 \%$ \\
\hline PF00512 & 40899 & 38442 & $6,01 \%$ & 12974 & 11469 & $11,60 \%$ \\
\hline PF00098 & 39496 & 38707 & $2,00 \%$ & 12016 & 11541 & $3,95 \%$ \\
\hline PF00009 & 37224 & 32402 & $12,95 \%$ & 11208 & 8559 & $23,63 \%$ \\
\hline PF00571 & 36014 & 30378 & $15,65 \%$ & 10094 & 7199 & $28,68 \%$ \\
\hline PF00132 & 36123 & 28941 & $19,88 \%$ & 10075 & 6476 & $35,73 \%$ \\
\hline PF00501 & 33063 & 30774 & $6,92 \%$ & 9197 & 8024 & $12,76 \%$ \\
\hline PF00016 & 34183 & 33417 & $2,24 \%$ & 9139 & 8738 & $4,39 \%$ \\
\hline PF00892 & 33687 & 2052 & $93,91 \%$ & 8912 & 56 & $99,37 \%$ \\
\hline PF01560 & 32118 & 1548 & $95,18 \%$ & 8080 & 37 & $99,54 \%$ \\
\hline
\end{tabular}


A determinação de quantos genes anotados cada família de proteína possui também contribui para a determinação de que famílias de proteínas não podem ser tratadas pela metodologia. A metodologia SIFTER se baseia em transferência de anotação através de uma árvore de genes. A retirada de genes sem anotação dos alinhamentos de cada família de proteína revelou que, para a versão 25 do banco de dados PFAM e versão 105 do banco GOA, 2308 famílias de proteínas não possuem sequer uma anotação de qualquer tipo que possa ser transferida.

Como observado no quadro III a retirada das sequências sem anotação não foi suficiente para que a metodologia possa ser amplamente aplicada, sendo ainda limitada pelo limite superior de memória requerido. Segundo o quadro I é possível observar a discrepância de número de anotações do tipo IEA em relação aos outros códigos de evidência, representando 99,6\% das anotações funcionais do GOA. Como observado na tabela 1 o código de evidência IEA é o código que possui a menor probabilidade a priori sendo, portanto, o de menor confiança. Realizamos testes com a retirada das sequências sem anotações e das sequências que possuíam somente anotações IEA. Os resultados estão apresentados no quadro IV. Como pode ser observado, a retirada das anotações do tipo IEA reduz o consumo de memória em mais de $99 \%$, permitindo que a análise seja realizada em máquinas com menor capacidade de memória.

Baseado nesta idéia foi implementado um sistema de filtragens, que retira do alinhamento múltiplo as sequências sem anotação dada uma seleção de códigos de evidência. A retirada das anotações com código de evidência IEA contribui também com a redução do tempo de execução e consumo de memória das fases de geração de árvore de genes, construção da árvore de espécies, reconciliação e preparação do arquivo "pli", com as anotações para cada família de proteínas. O consumo de memória e tempo de execução são reduzidos na mesma proporção obtida para a ferramenta de alinhamento múltiplo. 
Quadro IV - Redução de consumo de memória por remoção de proteínas anotadas com código IEA. Amostra das maiores famílias de proteínas, seu número de sequências (N) total, número de sequências anotadas retiradas as anotações do tipo IEA, a diferença entre o número total e o número de sequências anotadas, o uso de memória estimado para cada $\mathrm{N}$ e a diferença entre os consumos de memória estimados para a ferramenta MUSCLE.

\begin{tabular}{|c|c|c|c|c|c|c|}
\hline PFAM & $\mathbf{N}$ total & $\begin{array}{c}\mathrm{N} \text { anotadas } \\
\text { não-IEA }\end{array}$ & $\begin{array}{l}\text { Redução } \\
\text { de N - } \\
\text { anotadas } \\
\text { não-IEA }\end{array}$ & $\begin{array}{c}\text { Uso de } \\
\text { memória } \\
\text { estimado (MB) } \\
\text { ( } \mathrm{N} \text { total) }\end{array}$ & $\begin{array}{c}\text { Uso de } \\
\text { memória } \\
\text { estimado (MB) } \\
\text { (N anotadas } \\
\text { não-IEA) }\end{array}$ & $\begin{array}{l}\text { Redução no } \\
\text { consumo de } \\
\text { memória }\end{array}$ \\
\hline PF00005 & 163029 & 474 & $99,709 \%$ & 206408 & 37 & $99,98 \%$ \\
\hline PF00078 & 126258 & 23 & $99,982 \%$ & 124062 & 27 & $99,98 \%$ \\
\hline PF00115 & 118265 & 13 & $99,989 \%$ & 108658 & 21 & $99,98 \%$ \\
\hline PF00516 & 105452 & 5 & $99,995 \%$ & 86582 & 23 & $99,97 \%$ \\
\hline PF00400 & 101999 & 4 & $99,996 \%$ & 80262 & 11 & $99,99 \%$ \\
\hline PF00077 & 93675 & 91 & $99,903 \%$ & 67742 & 11 & $99,98 \%$ \\
\hline PF00096 & 88330 & 6 & $99,993 \%$ & 60060 & 10 & $99,98 \%$ \\
\hline PF00072 & 75322 & 221 & $99,707 \%$ & 44090 & 16 & $99,96 \%$ \\
\hline PF00033 & 70463 & 168 & $99,762 \%$ & 38541 & 14 & $99,96 \%$ \\
\hline PF02518 & 70410 & 22 & $99,969 \%$ & 38647 & 17 & $99,96 \%$ \\
\hline PF00528 & 70027 & 13 & $99,981 \%$ & 38378 & 21 & $99,94 \%$ \\
\hline PF07690 & 69503 & 1871 & $97,308 \%$ & 38720 & 138 & $99,64 \%$ \\
\hline PF00361 & 60333 & 3 & $99,995 \%$ & 28532 & 20 & $99,93 \%$ \\
\hline PF00069 & 56691 & 3 & $99,995 \%$ & 25827 & 55 & $99,79 \%$ \\
\hline PF00032 & 51006 & 232 & $99,545 \%$ & 20136 & 11 & $99,94 \%$ \\
\hline PF06817 & 50191 & 99 & $99,803 \%$ & 19423 & 10 & $99,95 \%$ \\
\hline PF00106 & 50144 & 397 & $99,208 \%$ & 19888 & 30 & $99,85 \%$ \\
\hline PF00583 & 46279 & 10 & $99,978 \%$ & 16660 & 12 & $99,93 \%$ \\
\hline PF00271 & 42435 & 10 & $99,976 \%$ & 14087 & 14 & $99,90 \%$ \\
\hline PF00126 & 41545 & 69 & $99,834 \%$ & 13344 & 10 & $99,92 \%$ \\
\hline PF00512 & 40899 & 139 & $99,660 \%$ & 12974 & 11 & $99,91 \%$ \\
\hline PF03466 & 40890 & 3 & $99,993 \%$ & 13247 & 20 & $99,85 \%$ \\
\hline PF00098 & 39496 & 6 & $99,985 \%$ & 12016 & 10 & $99,92 \%$ \\
\hline PF00009 & 37224 & 3 & $99,992 \%$ & 11208 & 35 & $99,69 \%$ \\
\hline PF00132 & 36123 & 32 & $99,911 \%$ & 10075 & 10 & $99,90 \%$ \\
\hline PF00571 & 36014 & 126 & $99,650 \%$ & 10094 & 12 & $99,89 \%$ \\
\hline PF00016 & 34183 & 6 & $99,982 \%$ & 9139 & 12 & $99,87 \%$ \\
\hline PF00892 & 33687 & 8 & $99,976 \%$ & 8912 & 13 & $99,85 \%$ \\
\hline PF00501 & 33063 & 6 & $99,982 \%$ & 9197 & 72 & $99,22 \%$ \\
\hline PF01560 & 32118 & 256 & $99,203 \%$ & 8080 & 14 & $99,83 \%$ \\
\hline
\end{tabular}

\subsection{Redução de redundância de processamento}

Analisando o código da implementação original do workflow Sifter foram encontrados vários trechos de código redundantes. São trechos independentes dos parâmetros de entrada e eram executados em cada utilização da ferramenta. Préexecutando estes trechos permite que haja somente a recuperação do resultado, 
ganhando tempo de execução. Posto isso, criamos um módulo de preparação de banco de dados e execução de código que era redundante na implementação original do worflow Sifter.

De forma geral, a fase de preparação dos dados realiza a conversão dos alinhamentos em formato stockholm (padrão do PFam) para o formato fasta para todas as famílias de proteínas; gera uma lista com todas as famílias de proteínas para a versão específica do PFam; cria um arquivo com as informações essenciais de anotações válidas do Gene Ontology Annotation, com as não-anotações removidas; cria um mapeamento dos genes presentes no PFam para suas espécies (NCBITaxID); gera uma lista com as famílias de proteínas não tratáveis pela anotação Sifter por não possuírem anotações a serem propagadas; prepara o arquivo function.ontology, a ontologia funcional do Gene Ontology em formato legado; prepara os arquivos em formato HMMER para a utilização pelo PfamScan; e prepara um arquivo com as relações taxonômicas do NCBI Taxonomy para a preparação das árvores de espécies. 


\section{Capítulo 6 CONCLUSÃO E PERSPECTIVAS}

Essa dissertação, com o título "Sifter-T: Um framework escalável para anotação filogenômica probabilística funcional de domínios protéicos.", tinha como proposta principal a elaboração de uma implementação da metodologia Sifter capaz de lidar com anotação funcional em larga escala e de forma acessível aos usuários.

Para alcançar tais objetivos realizamos o estudo da metodologia Sifter, sua implementação e qual era o público alvo principal, para uma abordagem mais objetiva. Após o estudo da metodologia Sifter e de sua implementação encontramos muitas oportunidades de aperfeiçoamento, algumas sem as quais a metodologia seria incapaz de se aproveitar dos bancos de dados atualizados. Encontramos também grandes dificuldades relacionadas à interação com o usuário, tanto na interface quanto na documentação e interpretação dos resultados. Com ajuda de estudantes das áreas biológica, de computação e de bioinformática estabelecemos que o usuário médio são cientistas da área biológica com conhecimentos básicos no uso de ferramentas de bioinformática e interessados principalmente na anotação funcional de seu próprio conjunto de genes. Com isso em mente buscamos soluções para as diversas questões encontradas, com foco no funcionamento simples e automatizado da ferramenta.

O resultado desta implementação é apresentado como Sifter-T (Sifter otimizado para Throughput), uma ferramenta open source de melhor usabilidade e velocidade em relação à implementação original do workflow de Sifter. A qualidade de anotação de Sifter-T é similar à da metodologia Sifter original, entretanto com maior número de famílias de proteínas tratáveis, aproveitamento completo dos códigos de evidência disponíveis e com anotações focadas nos domínios protéicos ao invés da sequência completa da proteína. Sifter-T foi escrito de forma modular em linguagem de programação Python; foi elaborado para simplificar a tarefa de anotação de genomas e proteomas completos; e os resultados são apresentados de forma a facilitar o trabalho do pesquisador. 
Durante o desenvolvimento da ferramenta utilizamos certos genomas e proteomas para testar a escalabilidade da ferramenta. Foram selecionados preferencialmente organismos de grupos taxonômicos distintos, mas de interesse para a área da Bioenergia. Os organismos foram:

Eubactérias:

- Escherichia coli*

- Leifsonia xyli xyli - Causadora do "raquitismo-da-soqueira" em cana-deacúcar.

Archeobactérias:

- Halobacterium salinarum

Fungos e leveduras:

- Saccharomyces cerevisiae*

- Neurospora crassa - Possuem enzimas de interesse para digestão de celulose.

Plantas:

- Saccharum officinarum - Principal matéria-prima para a fabricação do etanol no Brasil. Dados de EST.

Animais:

- Plasmodium vivax

* - Organismos bem estudados e com boa qualidade e quantidade de anotações tipo gene ontology.

As anotações de $E$. coli e de Saccharomyces cerevisiae tiveram a utilidade de averiguar se as anotações pela ferramenta Sifter-T são compatíveis com as anotações já conhecidas. As anotações dos organismos restantes estão sendo estudadas e enviadas a grupos que possam desenvolver avanços biológicos a partir destes resultados computacionais.

Posto isso, é possível afirmar que todos objetivos propostos foram alcançados. A ferramenta Sifter-T, principal resultado desta dissertação, está disponível nos endereços:

- http://labpib.fmrp.usp.br/methods/sifter-t/

- https://github.com/dcasbioinfo/sifter-t.git 
Este projeto de mestrado foi todo realizado no Laboratório de Processamento de Informação Biológica (LabPIB - http://labpib.openwetware.org), coordenado pelo Prof. Dr. Ricardo Z. N. Vêncio, e contou com a colaboração, em instantes distintos, dos estudantes de Iniciação Científica Ricardo Cacheta Waldemarin, Ariane Morassi Sasso e Marcel Alexandre Fenerich. 


\section{REFERÊNCIAS}

Altschul S.F., Gish W., Miller W., Myers E.W. and Lipman D.J. Basic local alignment search tool. 1990. J. Mol. Biol. 215: 403-410.

Bapteste E, O’Malley M a, Beiko RG, Ereshefsky M, Gogarten JP, Franklin-Hall L, et al. Prokaryotic evolution and the tree of life are two different things. Biology direct. 2009;4:34.

Bernstein, A. J. Program Analysis for Parallel Processing, IEEE Trans. on Electronic Computers. 1966.EC-15, :757-62.

Bolchini, D., Finkelstein, A., Perrone, V., \& Nagl, S. Better bioinformatics through usability analysis. Bioinformatics 2009 (Oxford, England), 25(3), 406-12. doi:10.1093/bioinformatics/btn633

Boratyn, G. M., Camacho, C., Cooper, P. S., Coulouris, G., Fong, A., Ma, N., Madden, T. L., et al. BLAST: a more efficient report with usability improvements. 2013. Nucleic acids research, 41(April), 29-33. doi:10.1093/nar/gkt282

Cock PJ a, Antao T, Chang JT, Chapman B a, Cox CJ, Dalke A, et al. Biopython: freely available Python tools for computational molecular biology and bioinformatics. Bioinformatics (Oxford, England). 2009 ;25(11):1422-3.

Conte, M. G., Gaillard, S., Droc, G., \& Perin, C. Phylogenomics of plant genomes: a methodology for genome-wide searches for orthologs in plants. 2008. BMC genomics, 9, 183. doi:10.1186/1471-2164-9-183Dargan T. Phylogenomic networks. Trends Microbiol. 2011;19(10):483-91.

de Matos, P., Cham, J. a, Cao, H., Alcántara, R., Rowland, F., Lopez, R., \& Steinbeck, C. The Enzyme Portal: a case study in applying user-centred design methods in bioinformatics. 2013. BMC bioinformatics, 14, 103. doi:10.1186/1471-2105-14103

Dimmer EC, Huntley RP, Alam-faruque Y, Sawford T, Martin MJ, Bely B, et al. The UniProt-GO Annotation database in 2011. Nucleic Acids Research. 2011;:1-6.

du Plessis L, Skunca N, Dessimoz C. The what, where, how and why of gene ontology-a primer for bioinformaticians. Briefings in bioinformatics. 2011;12(6).

Eddy SR. A probabilistic model of local sequence alignment that simplifies statistical significance estimation. PLoS computational biology. 2008;4(5):e1000069.

Edgar RC. MUSCLE: a multiple sequence alignment method with reduced time and space complexity. BMC bioinformatics. 2004;5:113. 
Edgar RC. MUSCLE: multiple sequence alignment with high accuracy and high throughput. Nucleic acids research. 2004 ;32(5):1792-7.

Edgar RC, Batzoglou S. Multiple sequence alignment. Current opinion in structural biology. 2006;16(3):368-73.

Eisen JA, Spring C. Phylogenomics: Improving Functional Predictions for Uncharacterized Genes by Evolutionary Analysis.Genome Research.1998;:163-7.

Eisen $\mathrm{J}$ a., $\mathrm{Wu} \mathrm{M}$. Phylogenetic Analysis and Gene Functional Predictions: Phylogenomics in Action. Theoretical Population Biology. 2002;61(4):481-7.

Eisen J a, Fraser CM. Phylogenomics: intersection of evolution and genomics. Science (New York, N.Y.). 2003;300(5626):1706-7.

Ekman D, Bjorklund AK, Frey-Skott J, Elofsson A: Multi-domain proteins in the three kingdoms of life: orphan domains and other unassigned regions. Journal of molecular biology 2005, 348(1):231-243.

Engelhardt BE, Jordan MI, Muratore KE, Brenner SE. Protein molecular function prediction by Bayesian phylogenomics. PLoS computational biology. 2005;1(5):e45.

Engelhardt BE, Jordan MI, Brenner SE. A graphical model for predicting protein molecular function. Proceedings of the 23rd international conference on Machine learning - ICML '06. 2006;:297-304.

Engelhardt BE. Predicting Protein Molecular Function [tese]. University of California at Berkeley; 2007.

Engelhardt BE, Jordan MI, Srouji JR, Brenner SE. Genome-scale phylogenetic function annotation of large and diverse protein families. Molecular and Cellular Biology. $2011 ;: 1969-80$.

Federhen S. The NCBI Taxonomy database. Nucleic acids research. 2012;40(Database issue):D136-43.

Finn RD, Mistry J, Tate J, Coggill P, Heger A, Pollington JE, et al. The Pfam protein families database. Database. 2010;38(November 2009):211-22.

Friedberg I. Automated protein function prediction, the genomic challenge. North. 2006;7(3).

Heckerman D. A Tutorial on Learning with Bayesian Networks. Technical Report MSR-TR-95-06, Microsoft Research, 1995.

Horner DS, Pavesi G, Castrignanò T, De Meo PD, Liuni S, Sammeth M, et al. Bioinformatics approaches for genomics and post genomics applications of nextgeneration sequencing. Briefings in bioinformatics. 2010;11(2):181-97. 
Innan $\mathrm{H}$, Kondrashov $\mathrm{F}$. The evolution of gene duplications: classifying and distinguishing between models. Nature Reviews Genetics. 2010;11(2):97-108.

Jöcker, A., Hoffmann, F., Groscurth, A., \& Schoof, H. Protein function prediction and annotation in an integrated environment powered by web services (AFAWE). 2008. Bioinformatics (Oxford, England), 24(20), 2393-4. doi:10.1093/bioinformatics/btn394

Katoh K, Toh H. Parallelization of the MAFFT multiple sequence alignment program. Bioinformatics (Oxford, England). 2010;26(15):1899-900.

Kodama Y, Shumway M, Leinonen R. The sequence read archive: explosive growth of sequencing data. Nucleic Acids Research. 2011;:1-3.

Koski T, Noble JM. Bayesian Networks: An Introduction. Ed John Wiley \& Sons, Ltd; 2009. 368pg.

Kristensen DM, Wolf YI, Mushegian AR, Koonin EV. Computational methods for Gene Orthology inference. Briefings in bioinformatics. 2011;12(5).

Maddison DR, Swofford DL, Maddison WP. Nexus: an extensible file format for systematic information. Systematic Biology. 1997;46(4):590-621.

Nahum L, Pereira S. Phylogenomics, Protein Family Evolution, and the Tree of Life: An Integrated Approach between Molecular Evolution and Computational Intelligence. Applications of Computational Intelligence. 2008;122(2008):259-79.

Pacheco, PS. Parallel programming with MPI. San Francisco: Morgan Kaufmann Publishers, Inc., 1997.

Pavelin, K., Cham, J. a, De Matos, P., Brooksbank, C., Cameron, G., \& Steinbeck, C. Bioinformatics meets user-centred design: a perspective. 2012. PLoS computational biology, 8(7), e1002554. doi:10.1371/journal.pcbi.1002554

Price MN, Dehal PS, Arkin AP. FastTree: computing large minimum evolution trees with profiles instead of a distance matrix. Molecular biology and evolution. 2009;26(7):1641-50.

Price M, Dehal P. FastTree 2 - Approximately Maximum-Likelihood Trees for Large Alignments. PLoS One. 2010;:1-20.

Punta M, Coggill PC, Eberhardt RY, Mistry J, Tate J, Boursnell C, et al. The Pfam protein families database. Nucleic acids research. 2012;40(Database issue):D290301.

Radivojac, P., Clark, W. T., Oron, T. R., Schnoes, A. M., Wittkop, T., Sokolov, A., Graim, K., et al. A large-scale evaluation of computational protein function prediction, 2013. 10(3). doi:10.1038/nmeth.2340 
Ram, K. Git can facilitate greater reproducibility and increased transparency in science. Source code for biology and medicine, 2013, 8(1), 7. doi:10.1186/1751-0473-8-7

Rentzsch, R., \& Orengo, C. a. Protein function prediction using domain families. BMC bioinformatics, 2013, 14 Suppl 3(Suppl 3), S5. doi:10.1186/1471-2105-14-S3-S5

Rodrigues APC, Grant BJ, Godzik A, Friedberg I. The 2006 automated function prediction meeting. BMC bioinformatics. 2007;8 Suppl 4:S1-4.

Sammut SJ, Finn RD, Bateman A. Pfam 10 years on: 10,000 families and still growing. Briefings in bioinformatics. 2008;9(3):210-9.

Sayers EW, Barrett T, Benson D a, Bolton E, Bryant SH, Canese K, et al. Database resources of the National Center for Biotechnology Information. Nucleic acids research. 2012;40(Database issue):D13-25.

Sjölander K. Phylogenomic inference of protein molecular function: advances and challenges. Bioinformatics. 2004;20(2):170-9.

Smith B, Ashburner M, Rosse C, Bard J, Bug W, Ceusters W, et al. The OBO Foundry: coordinated evolution of ontologies to support biomedical data integration. Nature Biotechnology. 2007;25(11):1251-5.

Sukumaran, J. and Mark T. Holder. DendroPy: A Python library for phylogenetic computing. Bioinformatics. 2010;26:1569-1571.

The Gene Ontology Consortium. The Gene Ontology: enhancements for 2011. Nucleic acids research. 2012;40(Database issue), D559-64. doi:10.1093/nar/gkr1028

The Uniprot Consortium. Reorganizing the protein space at the Universal Protein Resource (UniProt). Nucleic acids research. 2012;40(Database issue), D71-5. doi:10.1093/nar/gkr981

Treangen, T. J., \& Rocha, E. P. C. Horizontal transfer, not duplication, drives the expansion of protein families in prokaryotes. PLoS genetics, 2011, 7(1), e1001284. doi:10.1371/journal.pgen.1001284

van den Berg BHJ, Mccarthy FM, Lamont SJ, Burgess SC. Re-Annotation Is an Essential Step in Systems Biology Modeling of Functional Genomics Data. Plos One. 2010;5(5).

Veretnik, S., Fink, J. L., \& Bourne, P. E. Computational Biology Resources Lack Persistence and Usability. PLoS Computational Biology, 2008, 4(7), 2-4. doi:10.1371/journal.pcbi.1000136

Vernot B, Stolzer M, Goldman A, Durand D. Reconciliation with non-binary species trees. Journal of computational biology : a journal of computational molecular cell biology. 2008;15(8):981-1006. 
Whitfield EJ, Pruess M, Apweiler R. Bioinformatics database infrastructure for biotechnology research. Journal of biotechnology. 2006;124(4):629-39.

Zmasek CM, Eddy SR. A simple algorithm to infer gene duplication and speciation events on a gene tree. Bioinformatics. 2001;17(9):821-8. 